\title{
FIATAL FELNỐTTEK EGÉSZSÉGCÉLJAINAK VIZSGÁLATA: A CÉL MEGKÖZELÍTŐ-ELKERÜLŐ ORIENTÁCIÓJÁNAK SZEMÉLYES KONTEXTUSA ÉS A CÉLOKHOZ TÁRSULÓ SZUBJEKTÍV TAPASZTALATOK
}

\author{
CSUKA SÁRA IMOLA ${ }^{1 *}$ - ROSTA-FILEP ORSOLYA ${ }^{1}$ - DR. SALLAY VIOLA ${ }^{2}-$ \\ DR. MARTOS TAMÁS ${ }^{2}$ \\ ${ }^{1}$ Semmelweis Egyetem, Rácz Károly Doktori Iskola \\ ${ }^{2}$ Szegedi Tudományegyetem, Bölcsészettudományi Kar, Pszichológiai Intézet \\ Beérkezett: 2020. augusztus 15. - Elfogadva: 2021. február 20.
}

Háttér és célkitûzések: Egészséggel kapcsolatos céljaink szoros összefüggést mutatnak egészség-magatartásunkkal, így ennek vizsgálata fiatal felnôtteknél kiemelten fontos, mivel a fiatal ekkor alakítja ki saját életstílusát. A megközelító célok egy kívánt állapot elérésére, az elkerülô célok valamilyen kellemetlen állapottól való megszabadulásra vonatkoznak. Kutatásunk két fố irányát egyrészt a megközelitô egészségcélok személyes kontextusa, másrészt a céllal kapcsolatos kedvezố tapasztalatot övezö kontextuális tényezók azonosítása határozta meg.

Módszer: Keresztmetszeti és kérdôives vizsgálatunk mintáját 191 fiatal felnôtt alkotta. A célok mérésére a Személyes tervek (Little, 1993; Sheldon és Elliot, 1998; Martos, 2009b) kérdốvet alkalmaztuk. Ennek során a résztvevók maguk sorolták fel három egészséggel kapcsolatos személyes céljukat, majd ezek közül kellett egyet kiválasztaniuk és elöre megadott szempontok (pozitív és negatív érzelmek, énkonkordancia, énhatékonyság) szerint értékelniük. Ezt követôen történt a célok megközelítô/elkerülö kategóriákba sorolása. A megközelitố célorientáció elörejelzôinek vizsgálatára bináris regresszióelemzést, a célértékeléseket elôrejelzố kontextuális tényezók meghatározásához pedig három hierarchikus regressziós modellt épitettünk fel.

Eredmények: A cél személyes kontextusát képezö tényezôk közül a BMI kategória (túlsúlyos és elhizott) és a dohányzás (ritkán dohányzó és dohányzó) jelzik elôrre fordítottan a megközelítô egészségcél választásának nagyobb valószinüségét. A céllal együtt járó kedvezó tapasztalatokkal (pozitív érzelmek magasabb és negatív érzelmek alacsonyabb gyakorisága, cél magasabb énkonkordanciája, énhatékonyság) a cél megközelitố jellege következetesen együtt jár az egyéb tényezók hatásának kontrollálása mellett is.

Következtetések: Az eredmények afelé mutatnak, hogy a megközelítố orientáció alacsonyabb testtömegindexszel és kevesebb dohányzással jár együtt. Mindezek mellett a célokkal kapcsolatos szubjektív tapasztalatok egyedi összefüggéseket mutatnak a kontextuális tényezókkel. Eredményeink különféle egészséggel kapcsolatos, fiatal felnöttek számára kialakított intervencióknak is alapjául szolgálhatnak.

Kulcsszavak: bontakozó felnôttkor, Személyes tervek kérdốv, megközelitô-elkerülō egészségcélok, egészségmagatartás

" Levelezô szerzô, e-mail: saciimola@gmail.com

(C) 2021 A szerzố(k) 


\section{HÁTTÉR}

\section{Célok - egészségcélok}

A személy bárminemú tevékenységét irányító törekvéseit, motivációit céljaiban is megragadhatjuk (Austin és Vancouver, 1996; Martos, 2009a). A célok jellemzói ezáltal öszszefüggésben állnak a mentális és fizikai jólléttel (pl. Schwartz és Parisi, 2012; Schwartz és Drotar, 2009; Helgeson, 2018). A célok és az egészség - mentális és fizikai, sok esetben komplex - összefüggései számos tényezôvel magyarázhatók. Függnek attól, hogy mennyire állnak összhangban a személy érdeklődésével, értékeivel, ütköznek-e valamilyen akadályba, és mennyire könnyú a megvalósításuk, mennyire jellemzô a személyre az adott cél, vagy mennyi támogatást kap hozzá a környezetétôl (pl. Sheldon és Elliot, 1999; Milyavskaya és Werner, 2012; Schwartz és Parisi, 2012; Davis és mtsai, 2013; Martos, 2009b).

A célok egy speciális típusát képezik az egészséggel kapcsolatos személyes célok, melyek közé tartozik „minden olyan tevékenység, mely az egyén megjelenésével, egészségével, egészségi állapotának javításával, vagy erőnlétével kapcsolatos" (Peterman és Lecci, 2007, 331). Egy hazai kutatás eredményei szerint az emberek célrendszerének struktúrájában kiemelt jelentôségúek az egészséggel kapcsolatos aspirációk (Martos, Konkolÿ Thege és Kopp, 2010). Ezek a célok, az egészség-magatartással mutatott szoros összefüggésükból adódóan gyakran részét képezik különféle intervencióknak is. A célállítás módszere során az egészséges életmóddal kapcsolatos külsô meggyôzés és passzív edukáció helyett az egyéni aktivitására helyezik a hangsúlyt, és a személyesen fontos célok megfogalmazását és megvalósítását facilitálják (Strecher és mtsai, 1995; Mann, Ridder és Fujita, 2013).

\section{Megközelítô és elkerülō célok}

Elliot és Thrash (2002) a személyiség múködését meghatározó, nagy hagyománnyal bíró pszichológiai megközelítésekre alapozva (személyiségvonások, alapvetô diszpozíciók, motivációs rendszerek - BIS = Behavioral inhibition system/BAS = Behavioral approach system) alapvetốn kétféle motivációs tendenciát különböztet meg: a megközelítô és elkerülô temperamentumot, melyek örökölhetôk, és az élet során viszonylag stabilak. Ezek egyfajta neurobiológiai érzékenységre vezethetôk vissza; a megközelítô temperamentum a kívánatos/pozitív (jutalom), míg az elkerülô temperamentum a nemkívánatos/negatív (büntetés) jelzéseire érzékenyít. A célok, mint kognitív önszabályozó folyamatok, ezeknek az alapvetố hajlamosító tényezóknek a csatornáiként szolgálnak, megszabva ezek irányát és fókuszát, így tehát rugalmassá és tervszerúvé teszik a viselkedésünket, ami kifejezetten humánspecifikus képesség (Elliot és Sheldon, 1997).

A megközelítô és elkerülő célokat több kutatás is vizsgálta, bár ezek eltértek abban, hogy pontosan milyen mérési eljárást alkalmaztak a célok megragadására (Van Yperen, Blaga és Postmes, 2014). A megközelítô/elkerülő célok definiálása során kutatásunkban Elliot és Friedman (2007) meghatározását vettük alapul, eszerint megközelítônek tekinthetôk azok a személyes célok, melyek valamilyen eloonyös kimenetelre, vágyott 
végcélra fókuszálnak (például több gyümölcsöt fogyasztani, fittebbé válni), míg elkerülőnek azok, melyek valamilyen kellemetlen állapottól való megszabadulásra, vagy nemkívánatos kimenetel elkerülésére vonatkoznak (pl. kigyógyulni a derékfájdalomból, leszokni a dohányzásról).

A korábbi kutatások jó része az elkerülô célokat inkább negatív kimenetelekkel kapcsolta össze, mint például alacsonyabb általános szubjektív jólléttel, alacsonyabb szintû kompetenciaérzéssel és kontrolláltsággal (Elliot és Sheldon, 1997), fizikai tünetekkel (Elliot és Sheldon, 1998), szorongással (Elliot, Thrash és Murayama, 2012). A Sheldon és Elliot (1999) által bevezetett énkonkordancia fogalma arra utal, hogy a személy által kijelölt személyes célok milyen mértékú összhangot mutatnak stabil meggyôzôdéseivel és értékeivel. Az elkerülô célokat a személy alapvetô pszichológiai szükségleteivel inkongruensnek tartják, illetve kimutatták, hogy a kompetenciaérzés alacsonyabb szintje közvetíti a jóllét és az elkerüló célok közti fordított irányú összefüggést (Elliot és Sheldon, 1997). Az elkerülő orientáció egy általános érzelmi prediszpozícióból és hozzávetôlegesen állandó énpercepcióból is származhat (Elliot, Sheldon és Church, 1997). Az összefüggések hátterében ezenkívül egyéb okok is állhatnak; az elkerülő célok hatással lehetnek a perceptuális folyamatokra (negatív információra fordított nagyobb figyelem), a mentális kontrollra (koncentráció nehézsége), a memóriára (negatív információ könnyebb hozzáférhetôsége), az elhatározásokra (belsố kényszerként éli meg), valamint az érzelmi és viselkedéses válaszokra (Elliot és Friedman, 2007).

Egy más megközelítésbôl nézve azonban, pontosan a természetükból adódóan, a célok befolyásolhatják ezeknek a prediszpozícióknak a megnyilvánulási módjait. Tamir és Diener (2008) szerint, bár a megközelítô célok inkább előnyösebb kimenetelekkel, így például a magasabb énhatékonysággal és az élet értelmességének érzésével függnek össze, evolúciósan az elkerülô célok is ugyanolyan adaptívak lehetnek bizonyos körülmények között, és ez alapján a jólléttel mutatott összefüggésnek egyéni mintázatai is lehetnek. Egy frissebb vizsgálat szerint pedig egyetemi hallgatók következó szemeszterre vonatkozó céljai esetében nem a megközelítô-elkerüló jellemzô jósolta be a haladást, hanem hogy az adott cél megvalósítására autonóm okból, tehát saját belsô meggyôzôdéséből törekszik-e a személy (Werner, Milyavskaya és Koestner, 2018).

\section{Megközelitő / elkerülő egészségcélok}

Bár a korábbi általános célmérési kutatások során is megjelentek egészséggel kapcsolatos célok a válaszadóknál (pl. Sheldon és Elliot, 1998), kifejezetten az egészséggel kapcsolatos célok vonatkozásában a megközelítő-elkerülő orientáció szerepét elsôsorban a sport területén vizsgálták. A kutatások a megközelítô célok elônyös összefüggéseit emelik ki, így például kapcsolatban állnak a testmozgás gyakoriságával (Lochbaum és mtsai, 2013), az iskolai állapotfelmérô teszten mutatott jobb teljesítménnyel (Garn és Sun, 2009), összefüggést mutatnak a szubjektív mentális jólléttel és kompetenciaérzéssel (Castillo, Duda, Álvarez, Mercé és Balaguer, 2010; Warburton és Spray, 2013). Azonban az elkerülő célok nem minden esetben függtek össze negatív hatásokkal (Warburton és Spray, 2013; Garn és Sun, 2009; Lochbaum és Gottardy, 2015). 
Sôt olykor épp ellenkezóleg; például Korn és Elliot (2016) kutatása szerint nemcsak a fejlốdésre vonatkozó megközelítô, hanem az elkerüló célok is pozitív összefüggést mutatnak az intrinzik motivációval. Van Yperen és munkatársai (2014) a teljesítményre vonatkozó célok és a mérhetô teljesítmény összefüggéseit vizsgáló metaanalízisének eredményei szerint az akadémiai és munkahelyi területhez képest a sport bizonyos szempontból speciális jellegú. Szemben az elôbbi kettôvel, a jártasságra (saját képességeivel szemben támasztott elvárás), illetve teljesítményre (másokhoz viszonyított teljesítmény) vonatkozó elkerülô célok nem mutatnak negatív összefüggést a teljesítménnyel, mivel sok esetben ez már önmagában elegendô lehet a gyôzelemhez. A másokhoz képest mutatott teljesítmény ezenkívül sok sportágnak eredendôen része. Az eredményeket tovább árnyalja a végzett sport típusa (Warburton és Spray, 2013), a társas környezeti hatások (Castillo és mtsai, 2010; Garn és Sun, 2009) és a teljesítmény referenciapontja, mely lehet az egyén saját fejlődése vagy mások általi megítélése (Korn és Elliot, 2016).

Az egészségpszichológiai megközelítô-elkerülô orientációvizsgálatoknak tehát a testmozgás kitüntetett területét képezi, ugyanakkor az egészség-magatartás más összetevőinek kutatása némileg háttérbe szorult. Néhány vizsgálat rámutat azonban, hogy a megközelítô-elkerülő orientációnak kiemelt jelentôsége lehet például a dohányzásról való leszokásban vagy az egészséges táplálkozásban (Worth és mtsai, 2005; Sullivan és Rothman, 2008). A megközelítô-elkerülô jelleg összefüggést mutat továbbá azzal, hogy milyen - nyereségre, vagy pedig veszteségre fókuszáló - üzenetekre (pl. fogápolás, rákmegelőzés) fogékonyabb valaki (Hevey és Dolan, 2014; Sherman, Mann és Updegraff, 2006). Szerepe van azonban annak, hogy mire vonatkozik az adott egészségcél - a dohányzásról való leszokás esetében az elkerülố cél is lehet adaptív (Worth és mtsai, 2005) -, illetve hogy milyen szintû megvalósítási terv társul egy megfogalmazott célhoz (Sullivan és Rothman, 2008). Jelen vizsgálat során a személyes célok jellemzôit mértük, ami alatt a személy saját maga által megfogalmazott céljainak a kutatók által elóre definiált szempontok (esetünkben: pozitív és negatív érzelmek, énkonkordancia, énhatékonyság) szerint történô értékelését értjük (Martos, 2009a, 2009b).

\section{Készülődő felnôttkor - az egészséggel kapcsolatos magatartás kitüntetett idốszaka}

A bontakozó/készülô felnôttség, ahogyan Arnett nevezi (emerging adulthood, a továbbiakban a magyarul bevettebb fiatal felnôttkor terminológia helyett a speciálisabb készülődô felnôttség / kibontakozó felnôttkor elnevezést alkalmazzuk, ezzel is hangsúlyozva a korra jellemzô szabad kísérletezés és felfedezés szerepét) nagyjából 18 éves korban kezdôdik, és esetenként a húszas évek végéig is kinyúlik. Ez a fiatal felnôttkor idôszakán belül egy újonnan meghatározott, napjainkra jellemzó fejlôdési periódus. A korosztály jelentôs része még oktatásban, képzéseken vesz részt, és a magánéletben sem kötelezôdött el, így ezt az idôszakot az értékek alakulásának és a változásnak a szubjektív érzése jellemzi (Arnett, 2000). A bontakozó felnôttkor egyben az egészséggel kapcsolatos magatartás kiemelt idôszaka is. Az egyén életében ekkor bekövetkezô számos változás, mint például az önálló életvitel, a saját háztartás kialakítása az életmódot is érinti, és az ekkor kialakuló szokások rendszerint a felnôttkor során ké- 
sôbb is meghatározók maradnak (Helgeson és mtsai, 2014). A 2006-os Hungarostudy vizsgálat alapján idôsebb személyek több elkerülố aspirációt fogalmaztak meg, a roszszabbnak ítélt egészségi állapot fiataloknál inkább a megközelítô, idôsebbeknél pedig inkább az elkerülô célokkal állt összefüggésben, valamint a nôk és az alacsonyabb iskolai végzettséggel rendelkezók jellemzóbben elkerülô aspirációkat mutattak (Martos, Konkolÿ Thege és Kopp, 2010). Fontos hozzátenni azonban, hogy a vizsgálatok egybehangzó eredményei szerint a megközelítô célok összességében jóval nagyobb arányban fordulnak elô minden mintán (az elkerüló célok gyakorisága 10-36\% között mozgott a megközelító célokhoz képest). Ezek az arányok függetlenek voltak attól, hogy általános vagy kifejezetten az egészséggel kapcsolatos személyes célok vizsgálata állt középpontban (Elliot, Sheldon és Church, 1997; Elliot és Friedman, 2007; Worth és mtsai, 2005).

Jelen kutatásunk során az egészségen belül elsôsorban három területre, a dohányzásra, alkoholfogyasztásra és a testsúlyra összpontosítottunk, mivel a szerfogyasztás és a túlsúly hazánkban kiemelt népegészségügyi problémát jelentenek (Susánszky és Szántó, 2008). Emellett a készülô felnôttkor idôszaka a serdülőkorhoz képest csökkent szülôi kontroll és az identitás felfedezése nyomán az egészségügyi rizikó-magatartások szempontjából is kitüntetett idôszak (Arnett, 2000). Az ezt a korosztályt érố társas hatások is kiemeltek, ehhez kapcsolható a társas eseményekhez is köthetô szerfogyasztás (Pikó, 2017). Emellett nemcsak a jól meghatározható egészség-magatartással kapcsolatos mutatókat, hanem a személy szubjektív értékelését, így például testével való elégedettségét is erôsen közvetíthetik a társas közeg elvárásai (Pukánszky, 2014).

\section{Jelen kutatás - célkitúzések}

A megközelítő-elkerülô orientációval kapcsolatos eddigi vizsgálati eredmények tehát nem mutatnak egy irányba. A vizsgálatok többsége alapvetôen a megközelítô motivációt inkább elônyös, az elkerülô motivációt pedig inkább negatív kimenetelekkel hozza összefüggésbe (Elliot, Thrash és Murayama, 2012; Elliot és Thrash, 2002). Ugyanakkor a célok rugalmasan alakítják a viselkedést az adott szituációnak megfelelôen (Elliot és Sheldon, 1997). Kifejezetten a személyes egészségcélokra fókuszálva - és nem speciálisan valamilyen sportra vonatkozóan - ez idáig viszonylag kisszámú kutatást végeztek a megközelítô-elkerülô orientáció kapcsán, és ezek sem hoztak egyértelmú eredményeket. Ez feltehetôen részben az alkalmazott célmérési eljárások (például elôre megfogalmazott [Martos, Konkolÿ Thege és Kopp, 2010; Garn és Sun, 2009] vagy a személy által generált személyes célok [Worth és mtsai, 2005; Crombez és mtsai, 2016]) és a vizsgált egészség-magatartások sokféleségéból is adódik (Worth és mtsai, 2005; Sherman, Mann és Updegraff, 2006). Az egészséggel kapcsolatos célok vizsgálata fiatal felnôttkor idején kiemelten fontos, mivel a fiatal ekkor alakítja ki saját életstílusát (Helgeson és mtsai, 2014).

Ezek alapján kutatásunk két fô kérdés vizsgálata köré szervezôdött. Az elsô, hogy A) milyen személyes kontextusból emelkedik ki a megközelítô egészségcél? A cél személyes kontextusa alatt a nemet, testtömegindexet (Body Mass Index, BMI), a személy egészségére és testére vonatkozó szubjektív értékelését (egészségi állapot, testtel való elégedettség), 
illetve különféle egészség-magatartások megjelenését (testmozgás, alkoholfogyasztás, dohányzás gyakorisága) értjük, melyek együttesen hátterét képezhetik a megközelítô egészségcél választásának.

Ezek alapján a következó hipotéziseket fogalmaztuk meg:

a.1. A nem összefüggést mutat a megközelítő egészségcél választásával. A férfiak szignifikánsan nagyobb eséllyel választanak maguknak megközelítô egészségcélokat, mint a nốk.

a.2. A túlsúlyos és elhízott résztvevôk a normál BMI-vel rendelkezókhöz képest szignifikánsan kisebb eséllyel választanak maguknak megközelítő egészségcélokat.

a.3. A jobbnak ítélt egészségi állapot pozitívan függ össze a megközelító egészségcél választásával.

a.4. A testtel való elégedettség pozitívan függ össze a megközelítő egészségcél választásával.

a.5. A dohányzás gyakorisága fordított irányban függ össze a megközelítô egészségcél választásával.

a.6. Az alkoholfogyasztás gyakorisága fordított irányban függ össze a megközelítô egészségcél választásával.

a.7. A testmozgás gyakorisága pozitívan függ össze a megközelítô egészségcél választásával.

Második kutatási kérdésünk az volt, hogy B) a megközelitô egészségcél választása, kontrollálva a különféle kontextuális tényezôk hatását, hogyan függ össze a megközelítô célokhoz társuló céllal kapcsolatos személyes tapasztalatokkal? Céllal kapcsolatos személyes tapasztalatként jelen kutatásban a következóket vizsgáljuk: a cél megvalósítása során tapasztalt pozitív/ negatív érzelmek aránya, énkonkordancia és énhatékonyság a céllal kapcsolatban.

Ezzel kapcsolatban hipotéziseink a következők voltak:

A megközelítô egészségcél választása (a kontextuális tényezôk hatásának kontrollálása mellett is) összefüggést mutat a céllal kapcsolatos személyes tapasztalatokkal:

b.1. pozitív kapcsolatban áll a cél megvalósítása során tapasztalt pozitív érzelmekkel;

b.2. negatív kapcsolatban áll a cél megvalósítása során tapasztalt negatív érzelmekkel;

b.3. pozitív kapcsolatban áll a cél énkonkordanciájának mértékével;

b.4. valamint pozitív kapcsolatban áll a céllal kapcsolatos énhatékonysággal.

\section{MÓDSZER}

\section{Eljárás és adatgyüjtés}

A keresztmetszeti elrendezésû vizsgálatunk során hólabda módszert és kényelmi mintavételezést alkalmaztunk. A Szegedi Tudományegyetem pszichológia szakos hallgatói vettek részt a vizsgálati személyek toborzásában online formában, a kérdôív webes felületéhez tartozó link továbbításával. Mivel a tágabb kutatás, melynek keretein belül az adatfelvétel történt, egyetemi hallgatók tanulási céljaira irányult, a bevont személyek 
egyetemisták voltak, a tanult szak szempontjából minél változatosabb mintavételre törekedtünk. A teljes tesztcsomag kitöltése nagyjából 25-30 percet vett igénybe.

\section{Minta}

A vizsgálatból kizártuk a 19 évesnél fiatalabb és a 28 évesnél idôsebb válaszadókat, akik nem voltak valamilyen felsốoktatási intézmény hallgatói, illetve azokat a személyeket, akik valamilyen okból nem töltötték ki a teljes kérdôivet, így végül 197 fố adatait dolgoztuk fel.

\section{Mérốeszközök}

A következôkben a tesztcsomagban szereplô mérôeszközök közül csak a jelen tanulmány szempontjából releváns kérdôíveket mutatjuk be.

1. Alapadatok: A kitöltố életkora, neme (férfi: 0, nô: 1-es kód), anyagi helyzetével való elégedettsége és a választott egyetemi szak.

2. Személyes tervek kérdỗ (Little, 1993; Sheldon és Elliot, 1998; korábbi hazai vizsgálat ld. Martos, 2009b): A személyes célok felmérésére szolgáló eszköz. A kitöltố elôször rövid meghatározást olvashat azzal kapcsolatban, hogyan definiáltuk a személyes célokat: „Az Ön SZEMÉLYES CÉLJAINAK fogjuk nevezni azokat a célokat, pl. elhatározást, feladatot, tervet, vállalást, projektet, melyek megvalósitásával Ön valamilyen mértékben már most / folyamatosan foglalkozik (tehát nem a jövốben tervezi azt elkezdeni)." A kitöltés elsô lépéseként ezek alapján a saját maguk által megfogalmazott, minimum egy, maximálisan három egészséggel kapcsolatos cél megadása történt. Amennyiben több célt is megadott, a második lépésben a személynek ki kellett választania egészségcéljai közül azt, amelyiket a legfontosabbnak tartotta, majd ennek a céljának az értékelésére kértük: különféle általunk megadott állításokkal kapcsolatban kellett megjelölnie, hogy milyen mértékben ért egyet velük a kiválasztott céllal kapcsolatban $(1=$ kevéssé, keveset, ritkán -7 = nagyon, sokat, gyakran). Ezek a szempontok tulajdonképpen skálákként szolgáltak. A következó, korábban alkalmazott és vizsgált szempontok szerint történt az értékelés:

- Tervvel kapcsolatos pozitív és negatív érzések (hasonló eljárással: Martos és mtsai, 2013): A célhoz kapcsolódó pozitív („Milyen gyakran él át a mindennapokban pozitív érzelmeket [pl. örömöt, hálát, kíváncsiságot] ezzel a céllal kapcsolatban?") és negatív (Milyen gyakran él át a mindennapokban negatív érzelmeket [pl. stresszt, szomorúságot, szorongást vagy dühöt] ezzel a céllal kapcsolatban?”) érzelmeket mérô egy-egy állítás. A korábbi vizsgálatban (Martos és mtsai, 2013) alkalmazott eljáráshoz képest jelen vizsgálatban a pozitív és negatív érzelmekre vonatkozó állításokat egy-egy tétellé vontuk össze, ami a vizsgált konstruktumok globális és gyors értékelését teszi lehetôvé (Ittzés és mtsai, 2014).

- Énkonkordancia index (Sheldon és Elliot, 1999; Martos és mtsai, 2011): A motiváció internalizáltsági fokának megállapításához énkonkordancia mutató került kiszámításra, mely azt mutatja meg, milyen okból törekszik valaki célja megva- 
lósítására. Erre négy tétel vonatkozott a Sheldon és Elliot (1999) által meghatározott motivációt mérô skálából, a kitöltés során a válaszadó megjelölte, hogy egészségcélja hátterében mennyiben áll autonóm („...mert egyszerūen jó ezzel a céllal foglalkozni, örömöt és élvezetet jelent a megvalósítása”) vagy kontrollált szabályozás („Mert valaki ezt várja tôlem, vagy a helyzet megkívánja.”; „...mert közvetlen hasznom származik belôle [pl. anyagiak, siker]”; „...mert szégyellném magam, bûntudatom lenne vagy szoronganék, ha nem ezzel a céllal foglalkoznék"). Az elóbbivel való erôteljesebb egyetértés esetében magas, utóbbi esetben pedig alacsony énkonkordancia-értékrôl beszélhetünk. A mutató számítása során a kontrollált szabályozásra vonatkozó tételeket átlagoltuk, és kivontuk az autonómiatételbôl (relatív autonómia index), az autonómia tétel és a kontrollált itemek átlagértéke külön kezelve nem mutatott összefüggést, $r=0,02(p>0,05)$.

- Terv során tapasztalt énhatékonyság: A korábban Kopp és munkatársai vizsgálatában (1995) alkalmazott 10 tételes énhatékonyság skála rövidítésével született kérdôív, melynek rövidített változatát elsôként a Hungarostudy felmérésekben alkalmazták (Rózsa és mtsai, 2003). Az ötödik tételt („Rendelkezem a szükséges képességekkel ahhoz, hogy megvalósítsam ezt a célt.”) jelen kutatás céljaira fejlesztettük ki, mely a képességeket is hangsúlyozza az éndetermináció elmélet kompetenciafókuszának megfelelốen (ennek használhatóságát ellenôriztük: a négy- és öttételes változat közti erôs korrelációt kaptunk $[\mathrm{r}=0,98])$. A pontszámot az öt énhatékonyságot mérô tétel átlaga adja, pl. „Nem esik nehezemre, hogy kitartsak szándékaim mellett és elérjem ezt a célt.” (Cronbach $\alpha=0,82, \mathrm{~N}=5$ ).

A további elemzésekhez az elsô lépésben megadott célok megközelítő (1-es kód), illetve elkerülô (0 kód) kategóriákba lettek besorolva. A célok besorolását a két elsô szerzô végezte (kódolók közti egyetértés: $r=0,98$ ) Elliot és Friedman (2007) szempontrendszere alapján (Approach-Avoidance Personal Goals Coding System, 117-118.). A szempontrendszer szerint a megközelítô célok valamilyen pozitív kimenetelre fókuszálnak, mely felé el akar mozdulni a személy, vagy fenn akarja tartani. Például: „Izmosabb, ideálisabb testalkat elérése edzéssel”, „Haza tudjak biciklizni a suliból (elég magas hegyen lakom)”, „Minél több zöldséget fogyasztani”. Az elkerülő célok valamilyen negatív kimenetelre fókuszálnak, melyet a személy el akar kerülni, vagy meg akar szüntetni (pl. leszokni, csökkenteni, abbahagyni stb.). Például: „Fogyni 5 kg-ot”, „Nem eszek gyorséttermekben”. A kódolás során ezenkívül néhány kiegészítô szempontot érvényesítettünk, melyek a függelékben olvashatók.

3. Egyéb egészségre, elégedettségre és egészség-magatartásra vonatkozó kérdések:

- Általános egészségi állapot (Milyen az Ön egészsége általában? 5 = Nagyon rossz, 1 = Nagyon jó): Az egészségi állapot megítélése esetében nem volt olyan válaszadó, aki nagyon rossznak minôsítette egészségi állapotát. Az elemzések során a rossz és kielégítô kategóriákat a csoportok elemszámának kiegyenlítésére törekedve összevontuk. Elôbbi kategóriába esett a válaszadók 22,8\%-a (n = 45), $55,8 \%$-uk $(n=110)$ jónak, 21,3\%-uk $(n=42)$ pedig nagyon jónak ítéli egészségi állapotát.

- Dohányzás (Milyen gyakran dohányzik? 1 - Soha nem dohányzom, 7 - Naponta) 
Alkoholfogyasztás (Milyen gyakran iszik alkoholt? 1 - Soha nem iszom, 7 - Naponta): Az alkoholfogyasztás és dohányzás gyakorisága alapján három csoportot hoztunk létre: az alkoholt nem fogyasztók $(23,4 \%, \mathrm{n}=46)$, illetve a nem dohányzók csoportjába $(71,6 \%, \mathrm{n}=141)$ kerültek azok a kitöltôk, akik soha, vagy ritkábban, mint havonta fogyasztják ezeket, a havonta egy-két vagy több alkalommal alkoholt fogyasztók és dohányzók alkotják az alkoholt ritkán fogyasztók $(51,8 \%, \mathrm{n}=102)$, illetve a ritkán dohányzók $(10,2 \%, \mathrm{n}=20)$ csoportját. A rendszeresen alkoholt fogyasztó $(24,9 \%, \mathrm{n}=49)$, illetve dohányzó $(18,3 \%, \mathrm{n}=36)$ csoportot pedig azok a személyek, akik hetente egy-két alkalommal vagy ennél többször fogyasztanak alkoholt, illetve dohányoznak.

- Testmozgás gyakorisága (Meg tudná mondani, hogy az elmúlt 7 napban összesen hány napon végzett Ön intenzív testmozgást? Az intenzív testmozgás nagymértékú erôkifejtéssel jár, ennek következtében a légzés sokkal szaporább lesz a normálisnál. Idetartozik például súlyos tárgyak felemelése, ásás, aerobikozás vagy gyors kerékpározás. Csak olyan tevékenységekre gondoljon, amelyet legalább 10 percig megszakítás nélkül végzett! $0=$ Nem végzett, 7 = hét napon)

- A személy által megadott testsúly, valamint testmagasság, melyekból a testtömegindexet (Body Mass Index - BMI, $\mathrm{kg} / \mathrm{m}^{2}$ ) számítjuk ki. A további számítások során a bináris logisztikus regressziónál a WHO által is elkülönített BMI-kategóriákat vettük alapul, melyek a következôk (World Health Organization, 2020):

$-<18,5$ alultáplált

- 18,5-24,9 normális testsúlyú

- 25-29,9 túlsúlyos

- 30 s elhízott / obez

Mivel mintánkban az elhízott/obez kategóriába mindössze 8 fó tartozott, összevontuk a túlsúlyos kategóriával, így összesen három külön kategóriát különböztettünk meg (alultáplált - normális testsúlyú - túlsúlyos és elhízott).

- Testtel való elégedettség (Mennyire elégedett a testével? 1 = Teljes mértékben elégedetlen vagyok, 7 = Teljes mértékben elégedett vagyok)

\section{Statisztikai elemzés}

A statisztikai elemzéseket az IBM SPSS Statistics Version 25 programcsomag segítségével végeztük. Az eredmények feldolgozása során a leíró statisztikai elemzések után kétváltozós vizsgálatokat végeztünk a hipotézisek vizsgálatára alkalmazott elemzések elôkészítése céljából. Összehasonlítottuk a megközelítô és elkerülô célt választók csoportját független mintás t-próbákkal életkor, testmozgás gyakorisága, testtel való elégedettség, valamint a tervvel kapcsolatos személyes tapasztalatok tekintetében. Ezt követően Pearson-korrelációval vizsgáltuk a tervvel kapcsolatos tapasztalatok háttérváltozókkal mutatott összefüggéseit (a választott céltípus vizsgálata pontbiszeriális korrelációelemzéssel történt). Majd az egészségi állapot tekintetében történô összehasonlítás céljából független mintás, egyszempontos varianciaanalízist, a vizsgált változók nemmel mutatott összefüggéseinek vizsgálatára pedig szintén pontbiszeriális korrelációelemzést végeztünk. Hipotézisvizsgálatunk elsô lépéseként (A) bináris logisztikus regressziós elemzést, hipotéziseink második csoportjának (B) vizsgálatára 
pedig három (azonos módon felépített) hierarchikus regresszióelemzést végeztünk. Az alkalmazott statisztikai eljárásokat minden esetben az alkalmazhatóság feltételeinek ellenoórzése eloozte meg. A hipotézisvizsgálat részletes menetét az „Eredmények” fejezetben mutatjuk be.

\section{Etikai vonatkozások}

Az adatfelvételt egy egészségcélokkal kapcsolatos kutatás részeként végeztük, melyet az Egészségügyi Tudományos Tanács Kutatásetikai Bizottsága engedélyezett (ügyiratszáma: IV/2517-2/2020/EKU). A vizsgálati személyek a kutatás céljára és az adatkezelésre vonatkozóan részletes tájékoztatást olvastak a kutatás megkezdése elôtt. A beleegyezó nyilatkozatukkal kijelentették, hogy elmúltak 18 évesek, a vizsgálatban önként, anonim módon vesznek részt, annak folytatásától bármikor elállhatnak. A vizsgálat, valamint annak eredményeinek feldolgozása és azok összesített formában történô közlése során a résztvevôk személye nem beazonosítható. A vizsgálati személyek a kutatásban való részvételért semmilyen anyagi juttatásban nem részesültek.

\section{EREDMÉNYEK}

Mintánkat összesen 130 nô és 61 férfi válaszadó alkotta, átlagéletkoruk 22,44 év volt ( $\mathrm{SD}=1,96)$, a választott egyetemi szakok tekintetében mintánk összetétele jelentôs heterogenitást mutatott, azonban felülreprezentált volt az orvosi és pszichológia szakok elôfordulásának gyakorisága. Családi állapotukat tekintve 75,1\%-uk nôtlen, hajadon, 24,4\%-uk élettárssal él, és mindössze egy fő házas. A résztvevôk többsége (71,6\%-a) megközelítô egészségcélt választott ki értékelésre. Testtömegindex alapján a válaszadók többsége, 69,4\%-a a normális testsúlyú kategóriába tartozott, 9,8\%-uk alultáplált, 20,8\%-uk pedig a túlsúlyos vagy elhízott övezetbe volt sorolható.

A férfi hallgatók valamivel nagyobb arányban választottak megközelítô személyes egészségcélt a nôkhöz képest (77,6\% és 68,5\%), azonban ez az eltérés nem volt szignifikáns (Pearson $\left.\chi^{2}[\mathrm{df}=1, \mathrm{~N}=197]=1,820, \mathrm{p}=0,177 \varphi=0,096\right)$. A vizsgált változók leíró jellemzóit az 1. táblázat foglalja össze.

\section{A megközelítô és elkerülō egészségcélok: kétváltozós összefüggések}

Előzetes elemzésként azt vizsgáltuk meg, hogy mutatkozik-e eltérés a szociodemográfiai tényezôk, egészség-magatartás, jóllét és a tervekhez társuló tapasztalatok tekintetében azon hallgatók között, akik megközelítô, illetve akik elkerülô célt választottak ki értékelésre. A független mintás t-próbák eredményei szerint a megközelítô egészségcélt választók csoportja elégedettebb a testével, valamint az egészségcélja megvalósítása során jellemzôen gyakrabban élnek át pozitív és kevésbé gyakran negatív érzelmeket, valamint magasabb szintú énkonkordanciát és énhatékonyságot tapasztalnak meg (2. táblázat). 
1. táblázat. A vizsgált változók leíró értékei

\begin{tabular}{l|c|c|c|c|c}
\hline & Min. & Max. & M & S.E. & SD \\
\hline Egészségi állapot (tartomány: 1-5) & 2 & 5 & 3,96 & 0,05 & 0,72 \\
\hline $\begin{array}{l}\text { Testmozgás gyakorisága } \\
\text { (tartomány: 0-7) }\end{array}$ & 0 & 7 & 2,31 & 0,13 & 1,85 \\
\hline BMI-érték & 16 & 39,40 & 22,38 & 0,27 & 3,82 \\
\hline $\begin{array}{l}\text { Testtel való elégedettség } \\
\text { (tartomány: 1-7) }\end{array}$ & 1 & 7 & 4,42 & 0,16 & 1,50 \\
$\begin{array}{l}\text { Tervel kapcsolatos pozitív érzelmek } \\
\text { (tartomány: 1-7) }\end{array}$ & 1 & 7 & 4,41 & 0,12 & 1,67 \\
\hline $\begin{array}{l}\text { Céllal kapcsolatos negatív érzelmek } \\
\text { (tartomány: 1-7) }\end{array}$ & 1 & 7 & 3,54 & 0,14 & 1,91 \\
\hline $\begin{array}{l}\text { Cél énkonkordanciája } \\
\text { (tartomány: 1-7) }\end{array}$ & $-4,67$ & 6,00 & 1,57 & 0,17 & 2,36 \\
\hline $\begin{array}{l}\text { Cél során tapasztalt énhatékonyság } \\
\text { (tartomány: 1-7) }\end{array}$ & 1 & 7 & 5,15 & 0,08 & 1,12 \\
\hline
\end{tabular}

Megjegyzés:

$\mathrm{M}=$ átlag, $\mathrm{S} . \mathrm{E}$. = sztenderd hiba, $\mathrm{SD}=$ szórás

BMI (Body Mass Index, testtömegindex), folytonos változóként feltüntetve N = 197

2. táblázat. Független mintás t-próba: A megközelítô és elkerülố célt választók céllal kapcsolatos tapasztalatainak összehasonlítása

\begin{tabular}{|c|c|c|c|c|c|c|c|}
\hline & \multicolumn{2}{|c|}{ Megközelítô } & \multicolumn{2}{|c|}{ Elkerülô } & \multirow[b]{2}{*}{$\mathrm{t}$} & \multirow[b]{2}{*}{ df } & \multirow[t]{2}{*}{$\begin{array}{c}\text { Hatásméret } \\
(\mathrm{r})\end{array}$} \\
\hline & M & SD & $\mathrm{M}$ & SD & & & \\
\hline Életkor & 22,53 & 2,01 & 22,23 & 1,82 & 0,95 & 195 & 0,07 \\
\hline $\begin{array}{l}\text { Testmozgás gya- } \\
\text { korisága }\end{array}$ & 2,39 & 1,79 & 2,11 & 1,98 & 0,97 & 195 & 0,07 \\
\hline $\begin{array}{l}\text { Testtel való elége- } \\
\text { dettség }\end{array}$ & 4,55 & 1,42 & 4,07 & 1,64 & $2,06^{*}$ & 195 & 0,16 \\
\hline \multicolumn{7}{|c|}{ Tervvel kapcsolatos személyes tapasztalatok } & \\
\hline $\begin{array}{l}\text { Céllal kapcsolatos } \\
\text { pozitív érzelmek }\end{array}$ & 4,68 & 1,61 & 3,71 & 1,62 & $3,79 * * *$ & 195 & 0,29 \\
\hline $\begin{array}{l}\text { Céllal kapcsolatos } \\
\text { negatív érzelmek }\end{array}$ & 3,15 & 1,77 & 4,54 & 1,88 & $-4,86 * * *$ & 195 & $-0,36$ \\
\hline $\begin{array}{l}\text { Cél én- } \\
\text { konkordanciája }\end{array}$ & 2,17 & 2,15 & 0,10 & 2,24 & $6,03 * * *$ & 195 & 0,43 \\
\hline $\begin{array}{l}\text { Cél során tapasz- } \\
\text { talt énhatékony- } \\
\text { ság }\end{array}$ & 5,27 & 1,13 & 4,86 & 1,04 & $2,29 *$ & 195 & 0,16 \\
\hline Elemszám (N) & \multicolumn{2}{|c|}{$\begin{array}{c}141 \text { (férfi }=52 \\
\text { nô }=89)\end{array}$} & \multicolumn{2}{|c|}{$\begin{array}{c}56 \text { (férfi }=15 \\
\text { nô }=41)\end{array}$} & \multicolumn{3}{|c|}{$\begin{array}{c}\text { nemi különbségek (Pearson } \chi^{2} \\
(\mathrm{df}=1, \mathrm{~N}=197)=1,820 \\
\mathrm{p}=0,177 \varphi>=0,096)\end{array}$} \\
\hline
\end{tabular}

Megjegyzés:* $\mathrm{p}<0,05 ; * * \mathrm{p}<0,01 ; * * * \mathrm{p}<0,001$

$\mathrm{M}=$ átlag, $\mathrm{SD}=$ szórás, $\mathrm{df}=$ szabadsági fok BMI (Body Mass Index, testtömegindex) 
A Pearson-korreláció eredményei alapján a céllal kapcsolatos tapasztalatok egyike sem mutat összefüggést az életkorral (megjegyzendô azonban, hogy mintánk jellegzetességéból adódóan az életkor szórása alacsony volt, $\mathrm{SD}=1,96)$. A tervvel kapcsolatos tapasztalatokkal legjellemzóbben a választott cél típusa, a testtel való elégedettség és a testmozgás gyakorisága mutatott összefüggést. Nemek tekintetében is megfigyelhetünk egyes eltéréseket, a férfiak esetében nincs összefüggés a testtel való elégedettség és a cél énkonkordanciája között, illetve nôk esetében a dohányzás gyakorisága is öszszefüggést mutat a cél során tapasztalt pozitív, illetve negatív érzelmekkel, valamint az énkonkordanciával (részletesebben ld. 3. táblázat).

További összehasonlításokat végeztünk független mintás egy szempontos varianciaanalízissel a vizsgált kontextuális változók és a céljellemzók tekintetében a szubjektív egészségi állapot szerint létrehozott három csoport között (4. táblázat). Azokban az esetekben, ahol a varianciaanalízis szignifikáns különbségeket mutatott a csoportok között, post hoc vizsgálatot végeztük Hochberg's GT2 tesztet alkalmazva, mely jól kezeli a különbözô elemszámokat. Ennek eredményei szerint a rossz, kielégítô egészségi állapottal rendelkezôk ritkábban végeznek testmozgást, mint a jó $(p=0,001)$ vagy nagyon jó $(\mathrm{p}<0,001)$ egészségi állapottal rendelkezók. Továbbá kevésbé elégedettek a testükkel, mint a jó $(\mathrm{p}<0,001)$ vagy nagyon jó $(\mathrm{p}=0,003)$ egészségi állapottal rendelkezôk. A céllal kapcsolatos tapasztalatok tekintetében a rossz vagy kielégítô egészségi állapotú kitöltôk ritkábban élnek át pozitív érzelmeket választott céljukkal kapcsolatban, mint a nagyon jó egészségi állapottal rendelkezô személyek $(\mathrm{p}<0,001)$,

3. táblázat. Pearson-korreláció: a céllal kapcsolatos tapasztalatok egyéb változókkal mutatott összefüggései

\begin{tabular}{l|c|c|c|c|c|c|c|c|c|l}
\hline & 1 & 2 & 3 & 4 & 5 & 6 & 7 & 8 & 9 & 10 \\
\hline $\begin{array}{l}\text { 1. Választott } \\
\text { céltípus }\end{array}$ & - & 0,04 & 0,09 & $-0,06$ & $-0,17$ & $-0,17$ & $0,30^{*}$ & $-0,31^{*}$ & $0,47^{* * *}$ & 0,08 \\
\hline 2. Életkor & 0,06 & & $-0,35^{* *}$ & $-0,10$ & 0,18 & 0,04 & $-0,17$ & 0,04 & $-0,06$ & $-0,18$ \\
\hline $\begin{array}{l}\text { 3. Testmozgás } \\
\text { gyakorisága }\end{array}$ & 0,04 & $-0,09$ & - & 0,19 & $-0,180$ & $-0,16$ & $0,45^{* * *}$ & $-0,21$ & $0,40^{* *}$ & $0,34^{* *}$ \\
\hline $\begin{array}{l}\text { 4. testtel való } \\
\text { elégedettség }\end{array}$ & $0,21^{*}$ & 0,01 & 0,05 & - & 0,09 & 0,09 & 0,03 & $-0,26^{*}$ & 0,05 & $0,39^{* *}$ \\
\hline $\begin{array}{l}\text { 5. Dohányzás } \\
\text { gyakorisága }\end{array}$ & $-0,37^{* * *}$ & $-0,07$ & $-0,05$ & $-0,06$ & - & $0,46^{* * *}$ & $-0,17$ & 0,15 & $-0,05$ & 0,16 \\
\hline $\begin{array}{l}\text { 6. Alkohol- } \\
\text { fogyasztás } \\
\text { gyakorisága }\end{array}$ & $-0,09$ & $-0,10$ & 0,05 & 0,02 & $0,41^{* * *}$ & - & 0,07 & $-0,09$ & $-0,19$ & 0,04 \\
\hline $\begin{array}{l}7 . \text { Cél - pozitív } \\
\text { érzelmek }\end{array}$ & $0,25^{* *}$ & $-0,09$ & $0,44^{* * *}$ & 0,17 & $-0,12$ & 0,01 & - & $-0,33^{* *}$ & $0,48^{* * *}$ & $0,37^{* *}$ \\
\hline $\begin{array}{l}\text { 8. Cél - nega- } \\
\text { tív érzelmek }\end{array}$ & $-0,32^{* * *}$ & $-0,08$ & $-0,09$ & $-0,29^{* *}$ & $0,27^{* *}$ & 0,05 & $-0,42^{* * *}$ & - &,$- 051^{* * *}$ & $-0,33^{* *}$ \\
\hline $\begin{array}{l}\text { 9. Cél - én- } \\
\text { konkordancia }\end{array}$ & $0,37^{* * *}$ & 0,08 & $0,22^{*}$ & $0,28^{* *}$ & $-0,22^{*}$ & 0,01 & $0,21^{*}$ & $-0,37^{* * *}$ & - & $0,42^{* * *}$ \\
\hline $\begin{array}{l}\text { 10. Cél - } \\
\text { énhatékonyság }\end{array}$ & $0,18^{*}$ & $-0,03$ & $0,31^{* * *}$ & $0,30^{* * *}$ & 0,02 & 0,08 & $0,39^{* * *}$ & $-0,42^{* * *}$ & $0,42^{* * *}$ & - \\
\hline
\end{tabular}

Megjegyzés: $* \mathrm{p}<0,05 ; * * \mathrm{p}<0,01 ; * * * \mathrm{p}<0,001$

$\mathrm{N}_{\text {férfi }}=67, \mathrm{~N}_{\text {nố }}=130$ 
továbbá a nagyon jó egészségi állapottal rendelkezôk a jó egészségi állapotúakhoz képest $(\mathrm{p}=0,027)$ szintén több pozitív érzelmet élnek át. A cél során tapasztalt negatív érzelmek és az énkonkordancia esetében is csak a rossz, kielégítô és a nagyon jó egészségi állapottal rendelkezôk között volt különbség $(\mathrm{p}=0,003)$, utóbbi csoport ritkábban élt át negatív érzelmeket, ugyanakkor énkonkordánsabb egészségcélt választott. Az énhatékonyság esetében a rossz, kielégítô egészségi állapottal rendelkezô kitöltôk alacsonyabb énhatékonyságot tapasztaltak meg, mint a jó $(p=0,003)$ és a nagyon jó $(\mathrm{p}<0,001)$ egészségi állapotú csoport.

Pontbiszeriális korrelációelemzéssel vizsgáltuk továbbá a bevont változók nemmel mutatott összefüggéseit (4. táblázat), az alkoholfogyasztás és a céllal kapcsolatos negatív tapasztalatok esetében találunk közepes erôsségú összefüggést; a nôk ritkábban fogyasztanak alkoholt, ugyanakkor gyakrabban élnek át negatív érzelmeket egészséggel kapcsolatos személyes céljaik során.

\section{Hipotézisvizsgálat}

\section{Megközelitô egészségcél választását elôrejelzô kontextuális tényezók vizsgálata}

A hipotézisvizsgálat elsố lépésében bináris logisztikus regresszióval vizsgáltuk, hogy milyen személyes kontextus (nem, testtömegindex, egészségi állapot, testtel való elégedettség, testmozgás, alkoholfogyasztás, dohányzás gyakorisága) teszi valószínúbbé a megközelítô személyes egészségcél választását. Függô változóként tehát az egészségcél

4. táblázat. Csoportkülönbségek szubjektív egészségi állapot alapján, valamint a nem és a vizsgált változók közti összefüggések

\begin{tabular}{|c|c|c|c|c|c|c|c|c|c|}
\hline $\begin{array}{l}\text { Szubjektív egész- } \\
\text { ségi állapot }\end{array}$ & Életkor & $\begin{array}{l}\text { Testmoz- } \\
\text { gás gyako- } \\
\text { risága }\end{array}$ & $\begin{array}{c}\text { Testtel } \\
\text { való elé- } \\
\text { gedettség }\end{array}$ & $\begin{array}{l}\text { Dohány- } \\
\text { zás gyako- } \\
\text { risága }\end{array}$ & $\begin{array}{l}\text { Alkohol- } \\
\text { fogyasztás } \\
\text { gyakori- } \\
\text { sága }\end{array}$ & $\begin{array}{c}\text { Cél - } \\
\text { pozitív ér- } \\
\text { zelmek }\end{array}$ & $\begin{array}{c}\text { Cél - } \\
\text { negatív } \\
\text { érzelmek }\end{array}$ & $\begin{array}{c}\text { Cél - } \\
\text { én- kon- } \\
\text { kordancia }\end{array}$ & $\begin{array}{c}\text { Cél - } \\
\text { énhaté- } \\
\text { konyság }\end{array}$ \\
\hline $\begin{array}{l}\text { Rossz, kielégító } \\
(\mathrm{n}=45)\end{array}$ & $\begin{array}{c}22,51 \\
(\mathrm{SD}=, 06)\end{array}$ & $\begin{array}{c}1,33 \\
(\mathrm{SD}=1,35) \\
\end{array}$ & $\begin{array}{c}3,64 \\
(\mathrm{SD}=1,58)\end{array}$ & $\begin{array}{c}2,40 \\
(\mathrm{SD}=2,12)\end{array}$ & $\begin{array}{c}3,31 \\
(\mathrm{SD}=1,35) \\
\end{array}$ & $\begin{array}{c}3,80 \\
(\mathrm{SD}=1,67) \\
\end{array}$ & $\begin{array}{c}4,20 \\
(\mathrm{SD}=2,03) \\
\end{array}$ & $\begin{array}{c}0,81(\mathrm{SD}= \\
2,21)\end{array}$ & $\begin{array}{c}4,57 \\
(\mathrm{SD}=1,28)\end{array}$ \\
\hline Jó (n = 110) & $\begin{array}{c}22,44 \\
(\mathrm{SD}=1,89)\end{array}$ & $\begin{array}{c}2,47 \\
(\mathrm{SD}=1,95)\end{array}$ & $\begin{array}{c}4,63(\mathrm{SD}= \\
1,40)\end{array}$ & $\begin{array}{c}2,50 \\
(\mathrm{SD}=2,23)\end{array}$ & $\begin{array}{c}3,61 \\
(\mathrm{SD}=1,36)\end{array}$ & $\begin{array}{c}4,42 \\
(\mathrm{SD}=1,64) \\
\end{array}$ & $\begin{array}{c}3,53 \\
(\mathrm{SD}=1,87)\end{array}$ & $\begin{array}{c}1,59(\mathrm{SD}= \\
2,25)\end{array}$ & $\begin{array}{c}5,20 \\
(\mathrm{SD}=0,99)\end{array}$ \\
\hline $\begin{array}{l}\text { Nagyon jó } \\
(\mathrm{n}=42)\end{array}$ & $\begin{array}{c}22,38 \\
(\mathrm{SD}=2,38)\end{array}$ & $\begin{array}{c}2,93 \\
(\mathrm{SD}=1,66)\end{array}$ & $\begin{array}{c}4,69(\mathrm{SD}= \\
1,38)\end{array}$ & $\begin{array}{c}1,86(\mathrm{SD}= \\
1,76)\end{array}$ & $\begin{array}{c}3,43 \\
(\mathrm{SD}=1,25)\end{array}$ & $\begin{array}{c}5,13 \\
(\mathrm{SD}=1,46)\end{array}$ & $\begin{array}{c}2,88 \\
(\mathrm{SD}=1,66)\end{array}$ & $\begin{array}{c}2,38 \\
(\mathrm{SD}=2,57)\end{array}$ & $\begin{array}{c}5,66 \\
(\mathrm{SD}=0,96)\end{array}$ \\
\hline F-érték ${ }^{1}$ & 0,05 & $1428^{* * * 3}$ & $839^{* * *}$ & $1,80^{\mathrm{s}}$ & 0,88 & $7,59^{* *}$ & 5 & $5,02^{* *}$ & $11,68^{* * *}$ \\
\hline $\mathrm{df}$ & $2 ; 19$ & $2 ; 98,03$ & $2 ; 19$ & $2 ; 94,11$ & $2 ; 194$ & $2 ; 194$ & $2 ; 194$ & $2 ; 194$ & $2 ; 194$ \\
\hline $\operatorname{Nem}(r)^{2}$ & $-047^{*}$ & $-0,16$ & $-0,15^{*}$ & $-0,13$ & $-0,21^{* *}$ & 0,02 & $0,24^{* *}$ & 0,05 & $-0,14^{*}$ \\
\hline
\end{tabular}

Megjegyzés:

$* \mathrm{p}<0,05 ; * * \mathrm{p}<0,01 ; * * * \mathrm{p}<0,001$

${ }^{1}$ A csoportátlagok összehasonlítása független mintás egyszempontos varianciaanalízissel történt (a post hoc vizsgálatok eredményeit Id. a szövegben)

$\mathrm{df}=$ szabadsági fok

${ }^{3}$ Azokban az esetekben, ahol a Levene-teszt alapján nem teljesült a szóráshomogenitás feltétele, Welch-tesztet alkalmaztunk varianciaanalízis helyett

${ }^{2}$ A nem $(0=$ férfi, $1=$ nô $)$ és a vizsgált változók összefüggéseinek vizsgálata pontbiszeriális korrelációval (r) történt 
megközelítô (vs. elkerülő) jellege, prediktor változókként pedig a cél megfogalmazásának aktuális egyéni környezetével kapcsolatos, az elôzetesen lefolytatott kétváltozós elemzések nyomán is releváns változók (nem, egészségi állapot, dohányzás, alkoholfogyasztás, testmozgás gyakorisága, BMI-érték - ebben az elemzésben a tápláltsági határövezeteknek megfeleló bontásban kategoriális változóként kezelve, testtel való elégedettség) szerepeltek. A prediktor változókat egy lépésben, enter módszerrel bocsátottuk a modellbe, és megbizonyosodtunk a bináris logisztikus regresszió feltételeinek megvalósulásáról. Az eredmények alapján a dohányzás gyakoriságának (fordított irányú összefüggés), valamint a BMI-kategóriának (túlsúlyos és elhízott / obez) van statisztikai hatása a megközelítô egészségcél választásának esélyére. Továbbá a nem esetében láthatunk tendenciaszintû́ előrejelzô hatást (a nôk valamelyest nagyobb valószínúséggel neveztek meg megközelítô egészségcélt), azonban ez az összefüggés a statisztikai szignifikanciaszintet nem éri el. A bemutatott 5. táblázatban a szignifikáns prediktor változókat emeltük ki.

A választott egészségcéllal kapcsolatos pozitív tapasztalatokat elörejelző kontextuális tényezók vizsgálata

Hipotéziseink második csoportjának vizsgálatára párhuzamos módon négy hierarchikus regressziós modellt építettünk (6. táblázat), azt a kérdést tettük fel, hogy a meg-

5. táblázat. A szignifikáns prediktor változók

\begin{tabular}{|c|c|c|c|}
\hline \multicolumn{2}{|r|}{ Függố változó: megközelítô egészségcél választása } & $\mathrm{P}$ & EH [C.I. 95\%] \\
\hline \multirow{15}{*}{ 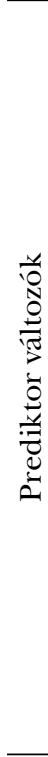 } & \multirow{2}{*}{\begin{tabular}{|l} 
Nem: nô (férfi: referencia kat.) \\
$\begin{array}{l}\text { Szubjektív egészségi állapot - rossz. kielégítố } \\
\text { (referencia kat.) }\end{array}$
\end{tabular}} & 0,067 & $0,44[0,18-1,06]$ \\
\hline & & & \\
\hline & Szubjektív egészségi állapot - jó & 0,406 & $1,63[0,52-5,11]$ \\
\hline & Szubjektív egészségi állapot - nagyon jó & 0,425 & $1,46[0,58-3,71]$ \\
\hline & Dohányzás - nem dohányzó (referencia kat.) & & \\
\hline & \begin{tabular}{|l} 
Dohányzás - nem dohányzó (referencia kat.) \\
Dohányzás(l) - ritkán dohányzó
\end{tabular} & 0,002 & $0,15[0,05-0,48]$ \\
\hline & Dohányzás(2) - dohányzó & 0,002 & $0,20[0,07-0,55]$ \\
\hline & \multicolumn{2}{|l|}{$\begin{array}{l}\text { Alkoholfogyasztás - alkoholt nem fogyasztó } \\
\text { (referencia kát.) }\end{array}$} & \\
\hline & $\begin{array}{l}\text { Alkoholfogyasztás }(1) \text { - alkoholt ritkán } \\
\text { fogyasztó }\end{array}$ & 0,225 & $0,55[0,21-1,45]$ \\
\hline & $\begin{array}{l}\text { Alkoholfogyasztás }(2) \text { - rendszeres } \\
\text { alkoholfogyasztó }\end{array}$ & 0,396 & $1,73[0,49-6,07]$ \\
\hline & Testmozgás gyakorisága / hét (nap) & 0,581 & $0,94[0,75-1,16]$ \\
\hline & \multicolumn{2}{|l|}{ BMI - normális testsúlyú (referencia kát.) } & \\
\hline & BMI(l) - alultáplált & 0,104 & $3,99[0,75-21,07]$ \\
\hline & BMI(2) - túlsúlyos & 0,029 & $0,37[0,15-0,91]$ \\
\hline & Testtel való elégedettség & 0,783 & $1,038[0,80-1,35]$ \\
\hline
\end{tabular}

Megjegyzés:

Megközelítố egészségcél: 1, elkerülố egészségcél: 0 , férfi: 0 , nố: 1, EH = esélyhányados.

C.I. = konfidencia intervallum

$\mathrm{N}=183$ 
közelítô egészségcél választása (az elkerülô cél választásához képest) független elôrejelzője-e a tervvel kapcsolatos tapasztalatoknak. Kimeneti változóként tehát a céllal, tervvel kapcsolatos személyes tapasztalatok (pozitív és negatív érzelmek gyakorisága a cél megvalósítása során, a cél énkonkordanciája és a megvalósítása során tapasztalt énhatékonyság), prediktorokként pedig az enter módszerrel mindhárom esetben elôször a kontextuális tényezôket (ld. a bináris regresszióelemzésbe beépített változókat)

6. táblázat. Hierarchikus regresszióelemzés: A választott egészségcéllal kapcsolatos pozitív tapasztalatokat előrejelzô tényezôk (standardizált béta együtthatók)

\begin{tabular}{|c|c|c|c|c|}
\hline \multirow[b]{2}{*}{ Modell } & \multicolumn{4}{|c|}{ Függố változók } \\
\hline & $\begin{array}{c}\text { Pozitív } \\
\text { érzelmek }\end{array}$ & $\begin{array}{l}\text { Negatív } \\
\text { érzelmek }\end{array}$ & $\begin{array}{c}\text { Én- } \\
\text { konkordancia }\end{array}$ & $\begin{array}{c}\text { Énhatékony- } \\
\text { ság }\end{array}$ \\
\hline \multicolumn{5}{|l|}{ 1. blokk } \\
\hline $\begin{array}{l}\text { Nem: nő (férfi referencia } \\
\text { kat.) }\end{array}$ & $0,14 *$ & 0,12 & $0,17 *$ & 0,01 \\
\hline $\begin{array}{l}\text { Szubjektív egészség: jó } \\
\text { (rossz, kielégítô referencia } \\
\text { kat.) }\end{array}$ & $-0,01$ & $-0,08$ & 0,01 & 0,06 \\
\hline $\begin{array}{l}\text { Szubjektív egészség: } \\
\text { nagyon jó (rossz, kielégítő } \\
\text { referencia kat.) }\end{array}$ & $0,14 *$ & $-0,15$ & 0,10 & $0,22 *$ \\
\hline $\begin{array}{l}\text { Dohányzás: ritka (nem } \\
\text { dohányzó referencia kat.) }\end{array}$ & 0,01 & $0,20 * *$ & 0,07 & 0,01 \\
\hline $\begin{array}{l}\text { Dohányzás: rendszeres } \\
\text { (nem dohányzó referencia } \\
\text { kat.) }\end{array}$ & $-0,04$ & $0,15^{*}$ & 0,05 & $0,18 *$ \\
\hline $\begin{array}{l}\text { Alkohol: ritka (alkoholt } \\
\text { nem fogyasztó referencia } \\
\text { kat.) }\end{array}$ & 0,08 & $-0,03$ & $0,20 *$ & 0,08 \\
\hline $\begin{array}{l}\text { Alkohol: rendszeres } \\
\text { (vs. alkoholt nem fogyasztó } \\
\text { referencia kat.) }\end{array}$ & 0,13 & $-0,05$ & $-0,06$ & 0,03 \\
\hline $\begin{array}{l}\text { Testmozgás gyakorisága / } \\
\text { hét (nap) }\end{array}$ & $0,45 * * *$ & $-0,05$ & $0,26 * * *$ & $0,29 * * *$ \\
\hline $\begin{array}{l}\text { BMI alultáplált (BMI } \\
\text { normális referencia kat.) }\end{array}$ & 0,06 & 0,09 & $-0,05$ & 0,01 \\
\hline $\begin{array}{l}\text { BMI túlsúlyos (BMI } \\
\text { normális referencia kat.) }\end{array}$ & $0,18 * *$ & $-0,28 * * *$ & 0,07 & 0,10 \\
\hline Testtel való elégedettség & 0,07 & $-0,30 * * *$ & $0,19 *$ & $0,27 * * *$ \\
\hline \multicolumn{5}{|l|}{ 2. blokk } \\
\hline Megközelítő egészségcél & $0,25 * *$ & $-0,25 * * *$ & $0,42 * * *$ & $0,16 *$ \\
\hline$\chi \mathrm{AR}^{2}$ (2. lépés) & 0,05 & 0,05 & 0,14 & 0,02 \\
\hline $\mathrm{R}^{2}$ & 0,33 & 0,35 & 0,31 & 0,29 \\
\hline $\mathrm{F}$ & $6,98 * * *$ & 7,53 & $5,34 * * *$ & $5,84 * * *$ \\
\hline
\end{tabular}

Megjegyzések:

$* \mathrm{p}<0,05 ; * * \mathrm{p}<0,01 ; * * * \mathrm{p} \leq 0,001$

Megközelítô egészségcél: 1, elkerülô egészségcél: 0, férfi: 0, nổ 1, N = 183 
bocsátottuk a modellbe annak érdekében, hogy kontrolláljuk ezen változók hatását, majd a második lépésben a cél megközelítô (vs. elkerülô) jellegét. Az eredmények alapján a vizsgált független változók a tervvel kapcsolatos negatív érzelmek dominanciáját jelzik előre legerôteljesebben, a teljes variancia 34,7\%-át magyarázzák, a pozitív érzelmek esetében 33\%, az énkonkordanciánál 30,9\%, az énhatékonyságnál pedig 29,2\% ez a magyarázóerô. A tervvel kapcsolatos tapasztalatokat legkövetkezetesebben a megközelítô terv választása, a testmozgás gyakorisága és a testtel való elégedettség jelzi elöre. Az egyes személyes célokkal kapcsolatos tapasztalatok azonban egyedi öszszefüggéseket is mutatnak, a pozitív érzelmek dominanciáját a magasabb BMI-érték és a jobb egészségi állapot, valamint a nem (a nôk gyakrabban élnek át pozitív érzelmeket céljaik megvalósítása során) jelzi előre. A negatív érzelmeket ezzel szemben a magasabb BMI-érték fordítottan jelzi előre, a dohányzás gyakorisága pedig pozitív kapcsolatban áll a negatív érzelmek gyakoriságával. Az énkonkordanciát a nem (nô) és a ritka alkoholfogyasztás, az énhatékonyságot pedig a jobbnak ítélt egészségi állapot és a gyakoribb dohányzás jelzi elôre.

\section{MEGBESZÉLÉS}

Jelen kutatás középpontjában a személyes egészségcélokban megjelenô megközelítô és elkerülő orientáció (Elliot és Thrash, 2002) és az egészség (mentális és fizikai) vizsgálata állt. Vizsgálatunkban egy olyan célmérési eljárást, a Személyes tervek kérdōívet (Little, 1993; Sheldon és Elliot, 1998; Martos, 2009b) alkalmaztuk, mely amellett, hogy stabil értékelési rendszert tesz lehetôvé, nem elôre megadott, hanem a válaszadó által generált és általa személyesen fontosnak tartott célokat tekinti az elemzés kiindulópontjának, és ezekhez a tervekhez közvetlenül kapcsolódó tapasztalatokon alapul. A vizsgálatba fiatal felnôtteket (19-28 éves korú egyetemistákat) vontunk be, mivel ez az önálló életvitel kialakításával összefüggésben (Arnett, 2000) az egészség-magatartás alakulása szempontjából kitüntetett idôszak (Helgeson és mtsai, 2014). Kutatásunk két fô kérdés mentén közelítette meg az egészség-magatartást; egyfelôl a cél választásának személyes kontextusát, valamint az egyes célokhoz kapcsolódó személyes tapasztalatokat és ezeknek a tapasztalatoknak az elörejelzôit vizsgáltuk. Az alábbiakban e két aspektus mentén tekintjük át részletesen az eredményeket.

\section{Megközelitố egészségcél választásának kontextusa}

Jelen vizsgálatban is, a korábbi kutatásokhoz hasonlóan (Elliot és Friedman, 2007; Worth és mtsai, 2005) a kitöltôk jelentôsebb arányban megközelító egészségcélt választottak ki értékelésre. Elsôként azt vizsgáltuk, hogy a megközelítô egészségcélok jellemzóen milyen kontextusból emelkednek ki.

Elsô hipotézisünk (a.1. hipotézis), mely szerint a nôk kevésbé hajlamosak megközelítố célt választani, nem igazolódott. Azonban a regresszióelemzés alapján a nók nagyobb eséllyel választanak megközelítô célt, ám ez az összefüggés csak tendenciaszintú 
volt. Ez a megfigyelhetố tendencia nem illeszkedik a korábbi kutatásokhoz (pl. Martos, Konkolÿ Thege és Kopp, 2010; Lochbaum és mtsai, 2013), például Lochbaum és munkatársai (2013) eredményeihez, mely szerint a nôk több elkerülố célt fogalmaztak meg. A következtetések levonásához azonban mindenképp indokolt lenne a nem szerepének további vizsgálata és férfi válaszadók nagyobb arányú bevonása. A magasabb testtömegindex (túlsúlyos és elhízott) fordított irányban jelezte előre a megközelítô cél választását, így tehát második hipotézisünk (a.2.) igazolást nyert. Ez az eredmény azt támaszthatja alá, hogy a BMI-értékben megmutatkozó optimális testsúly fenntartása összefüggést mutat a megközelítô motivációval (Sullivan és Rothman, 2008). Megjegyzendô ugyanakkor, hogy a testsúly csökkentésére vonatkozó célok, melyek szoros összefüggést mutathatnak a magasabb testtömegindexszel, mint például „fogyni 5 kg-ot”, „kevesebb cukrot enni”, szükségszerúen elkerülő célnak lettek kódolva. Bár Elliot és Friedman (2007, 97-118) szempontrendszere, mely mentén az egészségcélokat megközelítônek vagy elkerülônek kategorizáltuk, nagyban a nyelvi megfogalmazáson alapul, felmerül annak a kérdése, hogy mindez milyen mértékben adódik a célok megfogalmazásának módjából, és mennyiben tükröződik benne a személy alapvetô megközelítô/elkerülő orientációja.

A személyes cél kontextusát képezô további tényezôk közül a testtel való elégedettség és a jobbnak ítélt egészségi állapot sem jelezte előre a megközelítô egészségcél választását. Ez ellentmond azoknak a korábbi eredményeknek, melyek a megközelítô orientációt elônyösebb kimenetelekkel, az általános jóllét szempontjából magasabb élettel való elégedettséggel és önértékeléssel, az egészség-magatartás tekintetében gyakoribb testmozgással és a sportban mutatott magasabb szintû kompetencia érzésével hozták összefüggésbe (Castillo és mtsai, 2010; Lochbaum és mtsai, 2013; Warburton és Spray, 2013). Így az a.3. és 4. hipotézisünk nem nyert megerôsítést. Ennek hátterében mintánk sajátossága is állhat. Mivel krónikus betegséggel nem rendelkezô fiatalok céljai álltak a kutatás fókuszában, egészségi állapotukat túlnyomó többségben (70\%-ban) jónak vagy nagyon jónak minôsítették, elképzelhetô, hogy esetükben mindez kevésbé állt összefüggésben a megközelítô orientációval, illetve hogy a többi változó melletti hatása relatíve csekély. A testtel való elégedettség jelentôsége úgy tûnik, szintén nem kiemelkedô a többi vizsgált változó hatása mellett. Ugyanakkor, mivel a megközelítô egészségcélt választó hallgatók összességében elégedettebbek voltak a testükkel az elkerülô célt választókhoz képest, az elégedettség szerepének meghatározása további vizsgálatokat igényelne.

Vizsgáltuk még, hogy a különféle egészség-magatartások mennyiben jelzik elốre a megközelítô cél választását. A gyakoribb dohányzás fordított irányú összefüggést mutatott a megközelítô cél választásával (a.5. hipotézis). Azonban a dohányzásról való leszokást a magyar nyelv sajátosságaiból eredốen nehéz megközelítô cél formájában megfogalmazni. Így, akárcsak a BMI, a dohányzás esetében is megállapítható, hogy a dohányzásról való leszokásra vonatkozó célok nyelvi megfogalmazásuk alapján automatikusan elkerülô célként lettek kódolva. Sullivan és Rothman (2008) eredményei szerint a dohányzásról való leszokást az elkerüló célok is hatékonyan segíthetik, annak vizsgálata tehát, hogy a dohányzásra vonatkozó megközelítô célok milyen valószínûséggel valósulnak meg, további kutatásokat igényelne. Figyelemre méltó azonban, hogy az alkoholfogyasztás mint szerhasználat, már nem jelezte szignifikánsan elôre a 
megközelítô cél választásának valószínûségét (csak marginális prediktív erôvel rendelkezett), így a.5. hipotézisünk sem nyert igazolást. Ennek oka lehet, amellett, hogy mintánkban a rendszeres alkoholfogyasztók is csak igen alacsony arányban voltak reprezentálva ( 25\%), a dohányzásról való leszokással szemben a megfogalmazott célok között szinte alig jelent meg az alkoholfogyasztás csökkentésére vonatkozó cél. Úgy tûnik tehát, hogy a válaszadók számára ez kevésbé minôsült olyan törekvésnek, mely egészségi állapotuk szempontjából expliciten megfogalmazódott volna bennük. Ennek magyarázata lehet, hogy egyfelôl bizonyos mértékú alkoholfogyasztás a mai fogyasztói társadalmunk és ennek nyomán a társas események természetesnek tekintett része. Ezt Pikó (2008) „kultúrában gyökerezô addiktogén klímának” nevezi, ugyanakkor az alkoholfüggôség társadalmi megítélése kedvezôtlen, különösen nôk esetében (Madácsy, 2013). Ebbốl eredeztethetô latenciájából kifolyólag, ha valakinél vállaltan megjelenik egy ilyen cél, az már az alkoholfogyasztás egyértelmúbb problematikusságát jelezheti. A testmozgás gyakorisága nem volt szignifikáns előrejelzôje a megközelítố cél választásának, így a.7. hipotézisünket elvetettük. Ez az eredmény ellentmond azoknak a korábbi kutatásoknak, melyek a mozgás és a megközelító orientáció (Lochbaum és mtsai, 2013; Garn és Sun, 2009) szerepét emelik ki. Ugyanakkor néhány vizsgálat eredménye arra utal, hogy a megközelítô vagy elkerülő motiváció összefüggése összetettebb képet mutat a sport esetében, mint egyéb területeken (Van Yperen és mtsai, 2014; Lochbaum és Gottardy, 2015). Számít az is, hogy milyen jellegú sportról van szó (Warburton és Spray, 2013), illetve a testmozgással kapcsolatos elkerülô célok is lehetnek adaptívak - hiszen például a testmozgás jelentheti a „leadni 5 kg-ot” elkerülố cél megvalósítását is. A teljesítményre vonatkozó elkerülő célok, mint például a másokkal szembeni alulmaradás elkerülésére való törekvés, szintén elôrejelezhetik a sportban mutatott sikerességet (Van Yperen és mtsai, 2014). Korn és Elliot (2016) vizsgálata rámutat, hogy a sikerességen túl a fejlôdésre vonatkozó elkerülô cél az intrinzik motivációval is pozitív összefüggésben áll.

\section{A céllal kapcsolatos személyes tapasztalatokat előrejelzö tényezók}

Kutatásunk második részében azt vizsgáltuk, hogy van-e összefüggés a megközelítô egészségcél választása és a választott célhoz kapcsolódó személyes tapasztalatok között: a pozitív és negatív érzelmekkel, a cél énkonkordanciájával és az énhatékonyság érzésével. Az eredményeink szerint a célokat övezố kedvezô megtapasztalások, a kontextuális tényezôk hatásának kontrollálása mellett is, konzisztensen együtt jártak a megközelítô egészségcél választásával, ugyanakkor fordított összefüggés mutatkozott a negatív érzelmek gyakoriságával. Így megerôsítést nyert hipotézisünk (b.1. és b.2.), mely szerint a megközelítő egészségcélok pozitív összefüggést mutatnak a cél megvalósítása során tapasztalt pozitív, és fordított összefüggést a negatív érzelmekkel, ezáltal alátámasztást nyertek a korábbi vizsgálatok eredményei (Elliot és Sheldon, 1997; Elliot és Thrash, 2002).

Igazolódott továbbá, hogy a magasabb énkonkordanciát elôrejelzi a cél megközelítô jellege (b.3.). Ez fontos kiegészítése Werner és munkatársai kutatásának (2018), mely során egyetemisták akadémiai céljait vizsgálva azt az eredményt kapták, hogy mi- 
nél inkább autonóm motiváció áll a cél hátterében, annál nagyobb az elơrehaladás annak megvalósítása során. Ennek feltételezhetôen az az oka, hogy a magasabb énkonkordanciával bíró személyes célok - melyek gyakrabban járnak együtt a megközelítô motivációval - megvalósításába nagyobb energiát fektet a személy, kompetensebbnek érzi magát ezek véghez vitelében, illetve elérésük nagyobb mértékú jóllétet eredményez (Sheldon és Elliot, 1999; Elliot, Sheldon és Church, 1997).

Végül szintén alátámasztást nyert, hogy megközelítô célok esetében magasabb szintú énhatékonyságot tapasztal a személy (b.3.), ami illeszkedik azon kutatások sorába, melyek a megközelító célok véghez vitelében mutatott kompetencia és hatékonyság érzését, valamint az ezek megvalósításában mutatott jobb teljesítményt emelik ki (Warburton és Spray, 2013; Garn és Sun, 2009; Tamir és Diener, 2008). Összességében tehát a célhoz kapcsolódó jellemzók vizsgált összefüggései abba az irányba mutatnak, hogy a megközelítô célokat kedvezóbb tapasztalatok kísérik, emellett pedig a személyek hatékonyabbnak is érzik magukat ezek megvalósításában.

A megközelítô motiváción túl a célokkal kapcsolatos tapasztalatok esetében szignifikáns előrejelzônek bizonyult a cél kontextusát képezô változók közül a testmozgás gyakorisága, valamint a testtel való elégedettség. Egyedül a tervek során átélt pozitív és negatív érzelmek gyakorisága esetében nem következetes az összefüggés, ugyanis a testtel való elégedettség csak a negatív érzelmeket jelezte elôre fordított irányban, a testmozgás gyakorisága pedig a neg atív érzelmek gyakorisága esetében nem, csak a pozitív érzelmek gyakorisága esetében volt szignifikáns prediktor. Az itt megjelenô összefüggések feltételezhetôen a magasabb kompetenciaérzéshez és a megközelítő célok megvalósítása során mutatott nagyobb sikerességhez köthetôk (Lochbaum és mtsai, 2013; Garn és Sun, 2009). Így elképzelhetô, hogy ezek a személyek ritkábban küzdenek túlsúllyal, és ezzel is magyarázható a magasabb szintû testtel való elégedettség. Ugyanakkor az is felvethetô (akár az elóbbi ok mellett), hogy a testtel való elégedettség, mint szubjektív megítélés, egyben a magasabb mentális jóllét kifejezôdése is.

Mindezek mellett a célokkal kapcsolatos szubjektív tapasztalatok egyedi összefüggéseket is mutatnak a kontextuális tényezókkel. A pozitív érzelmek gyakoriságát a megközelítô cél választásán túl a nagyon jónak ítélt egészségi állapot és a magasabb testtömegindex jelezte elöre. A jobbnak ítélt egészségi állapot esetében ez az összefüggés nem meglepô, hiszen a fizikai egészség és az ezt feltételezhetően kísérô jó közérzet gyakran együtt jár a pozitív érzelmekkel is, míg a fizikai tünetek közvetlenül is negatív érzelmekhez vezethetnek (Ryan és Deci, 2001). Ugyanakkor az, hogy a magasabb testtömegindex elôrejelezte a pozitív érzelmeket a céllal kapcsolatban, többféle magyarázatot is felvet. Egyes eredmények szerint inkább a negatív érzelmi állapot vezet instrumentális evéshez (Macht és Simons, 2000), ami összefüggésben állhat a túlsúllyal. Elképzelhetô tehát, hogy az evés, mint egyfajta hedonikus tevékenység (Stroebe, Papies és Aarts, 2008) gyakoribb pozitív érzelmek átélését jelenti (Deci és Ryan, 2008). Mindez, bár az alacsony testtömegindex nem feltétlenül azonos a hedonikus orientáció hiányával, megerôsítheti azokat az eredményeket, melyek szerint az egészségi állapot (jelen esetben az esetleges túlsúly) csak elhanyagolható összefüggést mutat a hedonikus jólléttel, szemben az eudaimonikussal (Ryff, Singer és Love, 2004). Érdemes észben tartanunk azonban, hogy mintánk alapvetôen normális testsúlyú, fiatal nôkból állt, így alternatív felvetésként akár az is elképzelhetô, hogy az alacsonyabb (akár sovány) testsúly és 
az erre való törekvésben vagy ennek fenntartásában jelen lévô, esetleges neurotikus szorongás az, amiért az alacsonyabb BMI-vel jellemezhetố személyek kevesebb pozitív érzelmet élnek át a cél megvalósítása során (Hollin, Houston és Kent, 1985).

A negatív érzelmek gyakoriságát a magasabb testtömegindex fordítottan jelezte elôre, ami az elóbbiekben ismertetett pozitív tapasztalatokkal kapcsolatos eredményt jól kiegészíti. Ezenkívül a terv során átélt negatív érzelmek gyakorisága esetében a dohányzás gyakorisága is szignifikás prediktor volt. Tudjuk, hogy a latens hangulatzavarok és a dohányzás összefüggést mutat (Bácskai, Czobor és Gerevich, 2010), és bár mintánkat diagnózissal nem rendelkezô fiatal felnôttek populációja alkotta, ez jelezhet egyfajta összefüggést a célokkal kapcsolatos negatív érzelmek gyakorisága és a dohányzás között.

A cél énkonkordanciája esetében azt találtuk, hogy a cél megközelítô jellegének magyarázó erején túl a nemnek is van szerepe; a nôk valamivel énkonkordánsabbnak tartják választott személyes egészségcéljukat (függetlenül annak megközelítô vagy elkerülô jellegétôl). Bár Sheldon és Elliot (1999) vizsgálatában egyetemista kitöltôknél a nemnek nem volt szerepe, egy hazai vizsgálat (Martos, 2009b) során viszont a nôi válaszadók általános céljait magasabb fokú autonómia jellemezte. Bár az összefüggés nem erôteljes, így nem vonhatók le messzemenô következtetések, mindenképp további vizsgálatokat igényel. A cél magasabb énkonkordanciáját előrejelezte még a ritka alkoholfogyasztás is, míg a rendszeres alkoholfogyasztás nem függött össze az énkonkordanciával. Elképzelhetô, hogy arra a személyre, aki akár az alkoholfogyasztás irányába ható társas hatások ellenére is csak ritkán (nem heti rendszerességgel) fogyaszt alkoholt egyetemi évei alatt, lehet alapvetôen autonómabb szabályozás jellemzô, kevésbé érzékeny a társas nyomásra, és ezzel együtt általában véve énkonkordánsabb célokat is választ. Hozzá kell tennünk azonban, hogy az összefüggés nem volt erôteljes, és mindenképp további vizsgálatokat indikál.

A cél megvalósítása során tapasztalt énhatékonyságot, a már említett változókon túl, a jobbnak ítélt egészségi állapot és a gyakori dohányzás jelzi előre. Az elôbbi összefüggés esetében feltehetôen a rosszabbnak ítélt fizikai egészségi állapot az egészségcélok megvalósításában mutatott hatékonyságot is befolyásolja. Például, ha valakinek térdproblémája van, ez akadályozhatja bizonyos sportok végzésében. A dohányzás esetében már kevésbé kézenfekvô a magyarázat. Az is elképzelhetô, hogy ebben az a fajta illuzórikus kontroll jelenik meg, mely szerint sok dohányzó személy úgy érzi, bármikor abba tudja hagyni a dohányzást, illetve kevésbé számol annak negatív következményeivel. Masiero, Lucchiari és Pravettoni (2015) szerint ez a kognitív torzítás - az énhatékonyság érzésének megtartásán keresztül - az önértékelés fenntartását szolgálja. Azonban, különösen fiatalabb személyeknél, ez a fajta illúzió megnöveli a késóbbi erôs dohányzás kialakulásának kockázatát. Ugyanakkor más szerzők (Schwarzer és Fuchs, 1996) amellett érvelnek, hogy az énhatékonyság nem egyenlô az irreális optimizmussal, mivel valós cselekedeteken és a személyes kontroll érzésén alapul, ezáltal aktivitásra ösztönzi a személyt, így nagymértékben hozzájárul az egészség-magatartáshoz. 


\section{A kutatás korlátai}

Az eredmények általánosíthatósági körét szúkíti a nemi arányok eltolódottsága a nôi kitöltôk irányába és a kényelmi mintavételezés. Valamint keresztmetszeti és korrelációs kutatási elrendezésünkból adódóan nem vonhatóak le ok-okozatra vonatkozó következtetések. Például elképzelhetô, hogy a megközelítô motiváció eredményez nagyobb mértékú énhatékonyságot, ugyanakkor az is lehetséges, hogy az énhatékonyabb személyek alapvetôen megközelítô orientációval rendelkeznek.

Korlátként említhető, hogy a célok mérése során a személyeknek mindenképp meg kellett nevezniük legalább egy egészséggel kapcsolatos személyes célt. Így elképzelhetô, hogy maga a kérdés indukálta, hogy megfogalmazódjon egy ilyen terv. Valamint, bár az értékelése során láthatóvá váltak a célhoz kapcsolódó tapasztalatok, explicit módon nem adtunk lehetôséget a cél irrelevanciájának megjelölésére, mellyel ez kiküszöbölhetô lett volna. A célok besorolása kapcsán a Megbeszélés résznél már korábban említett megközelítő-elkerülő besorolás nyelvi dilemmái szintén felmerülnek az eredmények értelmezése során.

A vizsgálat további korlátja, hogy egyes konstruktumok mérésére, például a célok megvalósítása során tapasztalt pozitív és negatív érzelmek, testtel való elégedettség, csak egy-egy állítás vonatkozott, illetve hogy csak az intenzív testmozgás gyakoriságát vizsgáltuk. Ennek oka a minél több vizsgálati szempont bevonására való törekvés volt, illetve hogy a nagyobb kutatás során, melyben az adatok felvételre kerültek, az egészségügyi aspektus csak az egyik fókuszt jelentette. Egy jövôbeni vizsgálat során azonban mindenképp célszerú lenne ezen változók kiterjesztett skálákkal történô behatóbb vizsgálata. A célok mérése kapcsán felmerülô további korlát, hogy bár korábban validált vagy már alkalmazott skálákat vettünk alapul, ezeket módosítottuk a kutatás céljainak megfelelően.

A vizsgálat során az önbevalláson alapuló testmagasság- és testtömegértékekbôl számítottuk ki a BMI-t, mely ugyan együtt járást mutat az objektíven mért testtömegindexszel, mégis megjelennek torzító hatások (emlékezet, társas kívánatosság). Továbbá, bár a BMI a tápláltság becslésére széles körben alkalmazott mutató, kritikaként említhető ezzel kapcsolatban, hogy nem veszi figyelembe a testösszetételt (izom-zsír arány). Így akár az átlagosnál izmosabb testalkat magasabb testtömegindexet eredményezhet, valamint az életmódon túl egyéb tényezôk is hatással lehetnek rá (Bálint, Boros és Bakacs, 2019).

\section{Összefoglalás és kitekintés}

Kutatásunk során az egészség-magatartás kialakulása tekintetében kitüntetett életkori csoportot, fiatal felnôtteket vizsgáltunk, és a megközelítô-elkerülő orientáció kifejezetten egészségcélokhoz kapcsolt elemzését végeztük el. Az alkalmazott eljárás egyfelôl lehetôvé tette az egészségre irányuló célok széles spektrumának tanulmányozását, ugyanakkor a fókuszt szúkítette a tekintetben, hogy nem előre meghatározott, hanem a személy által definiált, vélhetôen legrelevánsabb tervek vizsgálatára került sor. Ezeket a célokat soroltuk be aztán megközelítô-elkerülô kategóriákba. 
Az egészségcél személyes kontextusát képezô tényezôk közül a normálisnál magasabb BMI, az egészség-magatartások közül pedig a dohányzás jelzi elốre a megközelítô egészségcél választását (fordított irányú összefüggés).

A kutatás igazolta továbbá, hogy a céllal együtt járó tapasztalatokat (pozitív és negatív érzelmek gyakorisága, a cél magasabb énkonkordanciája, magasabb énhatékonyság) a cél megközelítố jellege következetesen elôrejelzi az egyéb tényezôk hatásának kontrollálása mellett is. Az egészség-magatartás különféle módjai közül a testmozgás gyakorisága, a személy szubjektív értékelései közül pedig a testtel való elégedettség jelezte elôre a céllal együtt járó kedvezó tapasztalatokat.

Az eredmények tehát összességében afelé mutatnak, hogy a megközelító orientáció kevesebb dohányzással jár együtt (Lochbaum és mtsai, 2013; Sullivan és Rothman, 2008), ugyanakkor néhány vizsgált változó esetében kibontakozó összefüggések további kutatások tárgyát képezhetik.

A látszólagos ellentmondások feloldását segítheti, és az összképet kiegészítheti az elkerülő célok adaptivitásának vizsgálata is. Néhány korábbi vizsgálat felveti, hogy az elkerülố célok sem járnak együtt szükségszerúen kedvezôtlen egészség-magatartással. Így például a dohányzás esetében akár elônyösek is lehetnek azáltal, hogy mikor a személy megfogalmaz valamilyen negatív állapotot, az ettôl való elmozdulás mértékét folyamatosan monitorozni tudja (Worth és mtsai, 2005). Illetve ha megfelelô cselekvési terv kapcsolódik az elkerülô célhoz, annak megvalósítása ugyancsak sikeres lehet (Sullivan és Rothman, 2008).

Mivel fiatal, egyetemi hallgatók egészséggel kapcsolatos céljai álltak a kutatás középpontjában, érdemes lenne a késôbbiekben más korosztályokat, illetve különféle végzettséggel rendelkezô, esetleg valamilyen speciális krónikus betegséggel élô személyeket is bevonni annak megállapítása érdekében, hogy a feltárt összefüggések más csoportok esetében is hasonló mintázatot mutatnak-e. Egy korábbi hazai vizsgálat (Martos, Konkolÿ Thege és Kopp, 2010) például azt mutatta, hogy a kor elörehaladtával inkább az elkerülô célok kapnak hangsúlyt, illetve alacsonyabb végzettségú személyekre jellemzóbbek az elkerülố aspirációk.

Szintén érdemes lenne egyéb szempontként figyelembe venni, hogy a viselkedésváltozás mely szakaszában vannak a személyek (Lochbaum és mtsai, 2013), vagy milyen társas hatások érik ôket (Castillo és mtsai, 2010; Garn és Sun, 2009). Az egészségcélokon túlmenôen érdemes lenne más jellegú, így például munkával vagy magánélettel kapcsolatos személyes célokat is vizsgálni (Van Yperen és mtsai, 2014). Lényeges lenne a továbbiakban vizsgálni, hogy milyen hatása van a megközelítô, illetve az elkerülô orientációnak a viselkedésváltozásra hosszú távon (Lochbaum és mtsai, 2013), így a kapott eredmények akár alapját képezhetik a különféle célállítás módszerével kapcsolatos intervencióknak is. 


\section{IRODALOM}

Arnett, J. J. (2000). Emerging adulthood. A theory of development from the late teens through the twenties. The American Psychologist, 55(5), 469-480.

Austin, J., \& Vancouver, J. (1996). Goal Constructs in Psychology: Structure, Process, and Content. Psychological Bulletin, 120(3), 338-375.

Bácskai, E., Czobor, P., \& Gerevich, J. (2010). A dohányzás biológiai, szociális prediktorjellemzôi és az általános egészség percepciója - Biological and social predictors of smoking and perception of health. Orvosi Hetilap, 151(25), 1018-1027.

Bálint, L., Boros, J., \& Bakacs, M. (2019). Az önbevalláson alapuló testtömegindex használatának tapasztalatai: OTÁP adatok elemzése. Demográfia, 62(2-3), 271-299.

Castillo, I., Duda, J. L., Álvarez, M. S., Mercé, J., \& Balaguer, I. (2010). Motivational climate, approach-avoidance achievement goals and well-being in young soccer players. Revista De Psicologia Del Deporte, 20(1), 149-164.

Crombez, G., Lauwerier, E., Goubert, L., \& Van Damme, S. (2016). Goal pursuit in individuals with chronic pain: a personal project analysis. Frontiers in Psychology, 7. DOI: https://doi. org/10.3389/fpsyg.2016.00966

Davis, C. G., Egan, M., Dubouloz, C. J., Kubina, L. A., \& Kessler, D. (2013). Adaptation following stroke: a personal projects analysis. Rehabilitation Psychology, 58(3), 287-298.

Deci, E. L., \& Ryan, R. M. (2008). Hedonia, eudaimonia, and well-being: An introduction. Journal of Happiness Studies, 9(1), 1-11.

Elliot, A. J., \& Friedman, R. (2007). Approach-avoidance: A central characteristic of personal goals. In Little, B. R., Salmela-Aro, K., \& Phillips, S. D. (Eds), Personal project pursuit: Goals, Action, and Human Flourishing (pp. 97-118). New Jersey: Lawrence Erlbaum Associates Publishers.

Elliot, A., \& Sheldon, K. (1997). Avoidance achievement motivation: A personal goals analysis. Journal of Personality and Social Psychology, 73(1), 171-185.

Elliot, A. J., \& Sheldon, K. M. (1998). Avoidance personal goals and the personality-illness relationship. Journal of Personality and Social Psychology, 75(5), 1282.

Elliot, A. J., Sheldon, K. M., \& Church, M. A. (1997). Avoidance personal goals and subjective well-being. Personality and Social Psychology Bulletin, 23(9), 915-927.

Elliot, A. J., \& Thrash, T. M. (2002). Approach-avoidance motivation in personality: approach and avoidance temperaments and goals. Journal of Personality and Social Psychology, 82(5), 804-818.

Elliot, A. J., Thrash, T. M., \& Murayama, K. (2011). A longitudinal analysis of self-regulation and well-being: Avoidance personal goals, avoidance coping, stress generation, and subjective well-being. Journal of Personality, 79(3), 643-674.

Garn, A., \& Sun, H. (2009). Approach-avoidance motivational profiles in early adolescents to the PACER fitness test. Journal of Teaching in Physical Education, 28(4), 400-421.

Helgeson, V. S. (2018). Personal Projects and Psychological Well-Being: Emerging Adults With and Without Diabetes. Journal of Pediatric Psychology, 44(2), 176-185.

Helgeson, V. S., \& Takeda, A. (2009). Brief report: Nature and implications of personal projects among adolescents with and without diabetes. Journal of Pediatric Psychology, 34(9), 1019-1024.

Helgeson, V. S., Palladino, D. K., Reynolds, K. A., Becker, D. J., Escobar, O., \& Siminerio, L. (2014). Relationships and health among emerging adults with and without Type 1 diabetes. Health Psychology, 33(10), 1125-1133.

Hevey, D., \& Dolan, M. (2014). Approach/avoidance motivation, message framing and skin cancer prevention: A test of the congruency hypothesis. Journal of Health Psychology, 19(8), 1003-1012. 
Hollin, C. R., Houston, J. C., \& Kent, M. F. (1985). Neuroticism, life stress and concern about eating, body weight and apperance in a non-clinical population. Personality and Individual Differences, 6(4), 485-492.

Ittzés, A., Martos, T., Bóné, V., \& Dávid, B. (2014). Elégedettséget és hangulatot mérő egytételes skálák használhatósága jóllétre vonatkozó vizsgálatokban - Applicability of one-item scales for measuring satisfaction and mood in well-being research. Mentálhigiéné és Pszichoszomatika, 15(3), 171-186.

Kopp, M. S., Schwarzer, R., \& Jerusalem, M. (1995). Hungarian Adaptation of the General Self-Effcacy Scale. Freie Universität Berlin. Letöltve: 2021.02.05. http://userpage.fu-berlin.de/ health/hungar.htm

Korn, R. M., \& Elliot, A. J. (2016). The $2 \times 2$ Standpoints Model of Achievement Goals. Frontiers in Psychology, 7(742), 1-12.

Little, B. R. (1993). Personal Projects and the Distributed Self: Aspects of a Conative Psychology. The Self in Social Perspective: Psychological Perspectives on the Self, 4, 157-185.

Lochbaum, M., \& Gottardy, J. (2015). A meta-analytic review of the approach-avoidance achievement goals and performance relationships in the sport psychology literature. Journal of Sport and Health Science, 4(2), 164-173.

Lochbaum, M., Podlog, L., Litchfield, K., Surles, J., \& Hilliard, S. (2013). Stage of physical activity and approach-avoidance achievement goals in university students. Psychology of Sport and Exercise, 14(2), 161-168.

Macht, M., \& Simons, G. (2000). Emotions and eating in everyday life. Appetite, 35(1), 65-71.

Madácsy József (2013). „A mélypont ünnepe.” Az Anonim Alkoholisták Közössége Magyarországon. Doktori értekezés. Pécs: Pécsi Tudományegyetem Bölcsészettudományi Kar Interdiszciplináris Doktori Iskola.

Mann, T. L., De Ridder, D., \& Fujita, K. (2013). Self-regulation of health behavior: Social psychological approaches to goal setting and goal striving. Health Psychology, 32(5), 487-498.

Masiero, M., Lucchiari, C., \& Pravettoni, G. (2015). Personal fable: optimistic bias in cigarette smokers. International Journal of High Risk Behaviors és Addiction, 4(1), e20939.

Martos, T. (2009a). Célok, tervek, törekvések. I. Elméleti megfontolások és alkalmazási lehetôségek. Magyar Pszichológiai Szemle, 64(2), 337-358.

Martos, T. (2009b). Célok, tervek, törekvések. II. A személyes célok és életcélok kapcsolata módszertani kérdések és demonstráció. Magyar Pszichológiai Szemle, 64(3), 573-592.

Martos, T., Kézdy, A., \& Horváth-Szabó, K. (2011). Religious motivations for everyday goals: Their religious context and potential consequences. Motivation and Emotion, 35(1), 75-88. DOI: https://doi.org/10.1007/s11031-010-9198-1

Martos, T., Konkolÿ Thege, B., \& Kopp, M. S. (2010). Health aspirations in the context of age and self-rated health: Findings from a representative Hungarian sample. Journal of Health Psychology, 15(2), 269-278.

Martos, T., Sallay, V., \& Kézdy, A. (2013). Everyday goals, religious motivations, and well-being: The mediating role of emotions. Studia Psychologica, 55(3), 221-227. DOI: https://doi. org/10.21909/sp.2013.03.638

Milyavskaya, M., \& Werner, K. M. (2018). Goal Pursuit: Current State of Affairs and Directions for Future Research. Canadian Psychology, 59(2), 163-175.

Peterman, A. H., \& Lecci, L. (2017). Personal Projects in Health and Illness. In Personal Project Pursuit (pp. 329-354). Psychology Press.

Pikó, B. (2017). Függóségek és a mértéktelenség kultúrája. Valóság: Társadalomtudományi Közlöny, 60(3), 16-23.

Pukánszky, J. (2014). A karcsúságideál internalizációja és a testkép kapcsolata fiatal felnôtt nôk körében. Iskolakultúra, 24(7-8), 102-110. 
Rózsa, S., Réthelyi, J., Stauder, A., Susánszky, É., Mészáros, E., Skrabski, Á., \& Kopp, M. (2003). A HUNGAROSTUDY 2002 országos reprezentatív felmérés általános módszertana és a felhasznált tesztbattéria pszichometriai jellemzôi. Psychiatria Hungarica, 18(2), 83-94.

Ryan, R. M., \& Deci, E. L. (2001). On happiness and human potentials: A review of research on hedonic and eudaimonic well-being. Annual Review of Psychology, 52(1), 141-166.

Ryff, C. D., Singer, B. H., \& Dienberg Love, G. (2004). Positive health: connecting well-being with biology. Philosophical Transactions of the Royal Society of London. Series B: Biological Sciences, 359(1449), 1383-1394.

Schwartz, L. A., \& Drotar, D. (2009). Health-related hindrance of personal goal pursuit and well-being of young adults with cystic fibrosis, pediatric cancer survivors, and peers without a history of chronic illness. Journal of Pediatric Psychology, 34(9), 954-965.

Schwartz, L. A., \& Parisi, M. L. (2012). Self-identified goals of adolescents with cancer and healthy peers: Content, appraisals, and correlates. Journal of Pediatric Psychology, 38(2), 151-161.

Schwarzer, R., \& Fuchs, R. (1996). Self-efficacy and Health Behaviours. In Conner, M., \& Norman, P., Predicting Health Behaviour: Research and Practice with Social Cognition Models. Buckingham: Open University Press.

Sheldon, K. M., \& Elliot, A. J. (1999). Goal Striving, Need Satisfaction, and Longitudinal Well-Being: The Self-Concordance Model. Journal of Personality and Social Psychology, 76(3), 482-497.

Sherman, D. K., Mann, T., \& Updegraff, J. A. (2006). Approach/avoidance motivation, message framing, and health behavior: Understanding the congruency effect. Motivation and Emotion, 30(2), 164-168.

Strecher, V. J., Seijts, G. H., Kok, G. J., Latham, G. P., Glasgow, R., DeVellis, \& Bulger, D. W. (1995). Goal setting as a strategy for health behavior change. Health Education Quarterly, 22(2), 190-200.

Stroebe, W., Papies, E. K., \& Aarts, H. (2008). From homeostatic to hedonic theories of eating: Self-regulatory failure in food-rich environments. Applied Psychology: An International Review, 57(Suppl 1), 172-193.

Sulkers, E., Janse, M., Brinksma, A., Roodbol, P. F., Kamps, W. A., Tissing, W. J., \& Fleer, J. (2015). A longitudinal case-control study on goals in adolescents with cancer. Psychology és Health, 30(9), 1075-1087.

Sullivan, H. W., \& Rothman, A. J. (2008). When planning is needed: Implementation intentions and attainment of approach versus avoidance health goals. Health Psychology, 27(4), 438-444.

Susánszky, É., \& Szántó Zs. (2008). A magyar fiatalok (15-29 éves) egészségi állapota, egészségés rizikómagatartása és egészség-jövơképe. In Kopp M. (szerk.), Magyar lelkiállapot 2008 (pp. 200-206). Budapest: Semmelweis Kiadó.

Stroebe, W., Papies, E. K., \& Aarts, H. (2008). From homeostatic to hedonic theories of eating: Self-regulatory failure in food-rich environments. Applied Psychology, 57, 172-193.

Tamir, M., \& Diener, E. (2008). Approach-avoidance goals and well-being: One size does not fit all. In Elliot, A. J. (Ed.), Handbook of Approach and Avoidance Motivation (pp. 415-430). Lawrence Erlbaum.

Van Yperen, N. W., Blaga, M., \& Postmes, T. (2014). A meta-analysis of self-reported achievement goals and nonself-report performance across three achievement domains (work, sports, and education). PloS One, 9(4). Letöltve: 2020.07.10. https://www.ncbi.nlm.nih.gov/ pmc/articles/PMC3974764/

Vroman, K., Chamberlain, K., \& Warner, R. (2009). A personal projects analysis: Examining adaptation to low back pain. Journal of Health Psychology, 14(5), 696-706. 
Warburton, V., \& Spray, C. (2013). Antecedents of approach-avoidance achievement goal adoption: An analysis of two physical education activities. European Physical Education Review, 19(2), 215-231.

Werner, K. M., Milyavskaya, M., \& Koestner, R. (2018). Examining the role of approach-avoidance and autonomous-controlled motivation in predicting goal progress over time. Unpublished Manuscript.

World Health Organization (2020). Body mass index —BMI. Letöltve: 2021.01.14. http://www. euro.who.int/en/health-topics/disease-prevention/nutrition/a-healthy-lifestyle/bodymass-index-bmi

Worth, K. A., Sullivan, H. W., Hertel, A. W., Jeffery, R. W., \& Rothman, A. J. (2005). Avoidance goals can be beneficial: A look at smoking cessation. Basic and Applied Social Psychology, 27(2), 107-116.

\title{
FÜGGELÉK
}

A függelékként hivatkozott anyagok a tanulmány online változatának supplementumaként érhetôk el: https:/doi.org/10.1556/0016.2021.00013

\section{HEALTH GOALS IN EMERGING ADULTHOOD: THE PERSONAL CONTEXT OF APPROACH-AVOIDANCE GOAL ORIENTATION AND SUBJECTIVE EXPERIENCES ACCOMPANYING THESE GOALS}

\author{
CSUKA, SÁRA IMOLA - ROSTA-FILEP, ORSOLYA - DR. SALLAY, VIOLA - \\ DR. MARTOS, TAMÁS
}

\begin{abstract}
Background and aims: As our health goals show significant correspondence to our health behaviour investigation into these goals in emerging adulthood has unique importance as young adults establish their own lifestyle at that age. Approach goals refer to accomplishing a desired state, while avoidance goals refer to disposing an unpleasant state. Our research was built upon two main research questions: exploring the personal context of approach health goals and identifying possible contextual factors predicting advantageous experiences concerning the goal.

Methods: The sample of our questionnaire study consisted of 191 emerging adults. For capturing the goals the Personal Projects Questionnaire (Little, 1993, Sheldon \& Elliot, 1998, Martos, 2009b) was used. In the course of assessment, participants formulated their three goals concerning their health, then they had to choose one of these and rate it along some predefined aspects (positive and negative emotions, self-concordance and self-efficacy). Sequentially these goals were categorised into approach/avoidance categories. For predicting approach goal orientation binary logistic regression analysis was used and then three hierarchical regression analyses were built for identifying contextual factors which can be possible predictors of goal evaluations.

Results: Among factors framing the personal context of the goal BMI category (overweight and obese) and smoking (rarely and regular) predicted the odds of chosing an approach goal. Favourable experiences (higher levels of positive and lower levels of negative emotions, higher self-concordance, self-efficacy) accompanying these goals are associated with the approach nature of the goal consistently besides controlling for other factors.
\end{abstract}


Conclusions: Results indicate that approach orientation is accompanied by lower BMI index and less frequent smoking. Besides these subjective experiences concerning the goals show unique associations with contextual factors. Our findings can serve as starting-points of health-promoting interventions for young adults.

Keywords: emerging adulthood, Personal Projects Questionnaire, approach-avoidance health goals, health behaviour

A cikk a Creative Commons Attribution 4.0 International License (https://creativecommons. org/licenses/by/4.0/) feltételei szerint publikált Open Access közlemény, melynek szellemében a cikk bármilyen médiumban szabadon felhasználható, megosztható és újraközölhetô, feltéve, hogy az eredeti szerzó és a közlés helye, illetve a CC License linkje és az esetlegesen végrehajtott módosítások feltüntetésre kerülnek. (SID_1) 